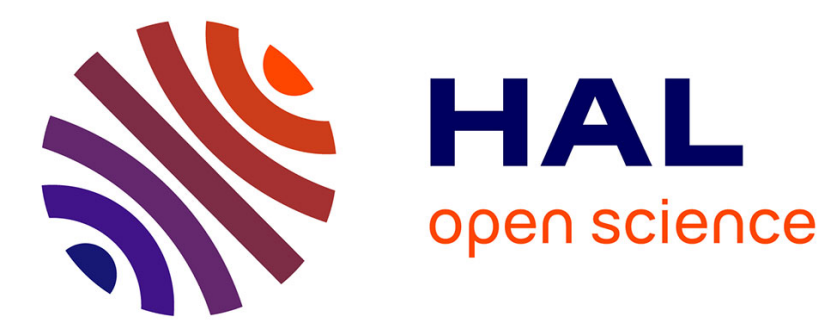

\title{
Metabolic Reprogramming by Reduced Calorie Intake or Pharmacological Caloric Restriction Mimetics for Improved Cancer Immunotherapy
}

\author{
Erwan Eriau, Juliette Paillet, Guido Kroemer, Jonathan Pol
}

\section{To cite this version:}

Erwan Eriau, Juliette Paillet, Guido Kroemer, Jonathan Pol. Metabolic Reprogramming by Reduced Calorie Intake or Pharmacological Caloric Restriction Mimetics for Improved Cancer Immunotherapy. Cancers, 2021, 13 (6), pp.1260. 10.3390/cancers13061260 . hal-03201001

\section{HAL Id: hal-03201001 \\ https://hal.sorbonne-universite.fr/hal-03201001}

Submitted on 17 Apr 2021

HAL is a multi-disciplinary open access archive for the deposit and dissemination of scientific research documents, whether they are published or not. The documents may come from teaching and research institutions in France or abroad, or from public or private research centers.
L'archive ouverte pluridisciplinaire HAL, est destinée au dépôt et à la diffusion de documents scientifiques de niveau recherche, publiés ou non, émanant des établissements d'enseignement et de recherche français ou étrangers, des laboratoires publics ou privés. 


\title{
Metabolic Reprogramming by Reduced Calorie Intake or Pharmacological Caloric Restriction Mimetics for Improved Cancer Immunotherapy
}

\author{
Erwan Eriau $^{1,2,3,4}\left(\mathbb{D}\right.$, Juliette Paillet ${ }^{3,4,5}$, Guido Kroemer $3,4,5,6,7,8,9$ (D) and Jonathan G. Pol ${ }^{3,4,5, *(\mathbb{D})}$ \\ 1 Centre de Cancérologie de Lyon, Université de Lyon, UMR Inserm 1052 CNRS 5286, Centre Léon Bérard, \\ 69008 Lyon, France; erw.eriau@gmail.com or erwan.eriau@inserm.fr \\ 2 Ecole Normale Supérieure de Lyon, 69342 Lyon, France \\ 3 Centre de Recherche des Cordeliers, Equipe 11 labellisée par la Ligue Nationale contre le Cancer, INSERM, \\ Sorbonne Université, Université de Paris, 75006 Paris, France; juliette.paillet@outlook.fr or \\ juliette.paillet@crc.jussieu.fr (J.P.); kroemer@orange.fr (G.K.) \\ 4 Gustave Roussy Cancer Campus, Metabolomics and Cell Biology Platforms, 94800 Villejuif, France \\ 5 Faculté de Médecine, Université Paris-Saclay, 91190 Kremlin-Bicêtre, France \\ 6 Institut Universitaire de France, 75005 Paris, France \\ 7 Pôle de Biologie, Hôpital Européen Georges Pompidou, Assistance Publique-Hôpitaux de Paris (AP-HP), \\ 75015 Paris, France \\ 8 Suzhou Institute for Systems Medicine, Chinese Academy of Sciences, Suzhou 215163, China \\ 9 Department of Women's and Children's Health, Karolinska University Hospital, 17164 Stockholm, Sweden \\ * Correspondence: pol_jonathan@yahoo.fr or jonathan.pol@inserm.fr; Tel.: +33-1-44-27-76-66
}

check for

updates

Citation: Eriau, E.; Paillet, J.;

Kroemer, G.; Pol, J.G. Metabolic

Reprogramming by Reduced Calorie

Intake or Pharmacological Caloric

Restriction Mimetics for Improved

Cancer Immunotherapy. Cancers 2021,

13, 1260. https://doi.org/10.3390/

cancers 13061260

Academic Editors: Marion R. Curtis and Abhinav P. Acharya

Received: 7 January 2021

Accepted: 8 March 2021

Published: 12 March 2021

Publisher's Note: MDPI stays neutral with regard to jurisdictional claims in published maps and institutional affiliations.

Copyright: (c) 2021 by the authors. Licensee MDPI, Basel, Switzerland. This article is an open access article distributed under the terms and conditions of the Creative Commons Attribution (CC BY) license (https:/ / creativecommons.org/licenses/by/ $4.0 /)$.
Simple Summary: Reduced food intake significantly enhances healthy lifespan in both model animals and humans, and decreases the incidence of cancer and other age-related diseases. This beneficial effect is mediated by the cellular knock-on effects of reduced food intake. Interestingly, these effects differ between cancer and healthy cells because cancer cells have peculiar metabolic requirements. Some compounds called "caloric restriction mimetics" are able to recapitulate the effects of reduced food intake without impacting the nutritional status. Reduced food intake and these mimicking agents are both able to enhance responses to some chemotherapies, as well as to some regimens combining chemotherapy and immunotherapy. There are encouraging preclinical data supporting the use of reduced food intake or caloric restriction mimetics as an adjuvant to cancer chemo-immunotherapies. Clinical data are sparse, but generally favorable, and additional trials are ongoing.

Abstract: Caloric restriction and fasting have been known for a long time for their health- and life-span promoting effects, with coherent observations in multiple model organisms as well as epidemiological and clinical studies. This holds particularly true for cancer. The health-promoting effects of caloric restriction and fasting are mediated at least partly through their cellular effects-chiefly autophagy induction - rather than reduced calorie intake per se. Interestingly, caloric restriction has a differential impact on cancer and healthy cells, due to the atypical metabolic profile of malignant tumors. Caloric restriction mimetics are non-toxic compounds able to mimic the biochemical and physiological effects of caloric restriction including autophagy induction. Caloric restriction and its mimetics induce autophagy to improve the efficacy of some cancer treatments that induce immunogenic cell death (ICD), a type of cellular demise that eventually elicits adaptive antitumor immunity. Caloric restriction and its mimetics also enhance the therapeutic efficacy of chemo-immunotherapies combining ICD-inducing agents with immune checkpoint inhibitors targeting PD-1. Collectively, preclinical data encourage the application of caloric restriction and its mimetics as an adjuvant to immunotherapies. This recommendation is subject to confirmation in additional experimental settings and in clinical trials. In this work, we review the preclinical and clinical evidence in favor of such therapeutic interventions before listing ongoing clinical trials that will shed some light on this subject. 
Keywords: cancer immunotherapy; metabolism; fasting; caloric restriction; caloric restriction mimetics

\section{Introduction}

Fasting and caloric restriction $(\mathrm{CR})$ were shown in non-human primates to reduce the incidence of not only cancer but also metabolic diseases, arteriosclerosis, and neurodegeneration [1-5] — thus extending the healthspan. Furthermore, fasting and CR were shown in yeast, plants, worms, flies, and rodents to prolong lifespan [6-8] and reduce the incidence of a wide array of age-associated pathologies, notably malignant diseases [9]. Fasting-mimicking-diets (FMDs) reproduce the effects of fasting while maintaining a food supply, yet with a limited number of calories and a particular macronutrient composition, frequently poor in proteins, enriched in unsaturated fats, and with low to moderate proportions of carbohydrates. FMDs were shown in pilot trials to reduce risk factors associated with aging, diabetes, cardiovascular disease and cancer, without major adverse effects [10-13]. Of note, CR promotes both lifespan and healthspan, whereas exercise (and the associated increased calorie expenditure) has only been shown to prolong healthspan, [14] which hints at molecular effects of CR that go beyond its effects on energy balance. In humans, fasting is defined as a severe to complete deprivation of food intake (0-500 kcal/day) for several hours to days. We distinguish between continuous fasting, which can last over 40 consecutive days, and intermittent fasting, which exists under different patterns such as $16 \mathrm{~h}$ a day, 1 day out of 2 , or 5 days per week $[15,16]$. By contrast, CR is typically defined as a long-term reduction by $10-50 \%$ of the recommended daily calorie intake [5,17]. FMDs are varied but usually involve at least short-term CR alongside other dietary modifications, often reduction in protein intake and sometimes supplementation with micronutrients such as vitamins. In this review, when indistinctively referring to fasting, CR, and/or their mimetics, we will use the term "energy reduction" (ER).

\section{Clinical Evidence of the Health Benefits of ER}

Inhabitants of the Okinawa island in Japan are renowned for their particularly long healthspan and lifespan, which is attributed by some to prolonged episodes of mild ER as well as consumption of nutrients exhibiting CR-mimicking properties [18]. The three-site CALERIE Phase 1 trial [19-21] was the first to investigate the effects of sustained (six months) $\mathrm{CR}$ in healthy volunteers as compared to various other metabolic interventions. On one site, patients undergoing prolonged $\mathrm{CR}$ showed a reduced pre-prandial insulin level and body temperature (two biomarkers of longevity in humans) [22]. CR had no impact on cortisol levels [23]. The CALERIE Phase 2 trial [24-26] followed 218 healthy non-obese volunteers across three institutions in a 2:1 randomized single-blind trial of a two-year 25\% $C R$ versus an ad-libitum control. CR significantly increased health-related quality-of-life (QOL) [27], decreased whole-body oxidative stress [28,29] (a marker of aging), and more generally slowed biological aging [30]. One of the smaller Phase 1 trials [20] showed that CR-induced weight loss was associated with a reduction in bone-density, an effect that was not associated with exercise-induced weight-loss [31]. However, this finding was not verified in the (larger) Phase 2 trial where no significant difference in adverse effects was witnessed between treatment and control groups [32]. This observation supports the safety of $\mathrm{CR}$ interventions. Moreover, prolonged moderate $\mathrm{CR}$ without exercise does not seem to compromise aerobic capacity [33]. Other trials have associated FMDs with improvements in a range of biomarkers of aging and age-related diseases [34].

Unsurprisingly, clinical trials revealed weight-loss proportionate to the intensity and duration of CR $[11,22,35-37]$ and a corresponding increase in the percentage of fat-free mass [38]. Around half of the CR-induced weight-loss was maintained two years after completion of the intervention [39]. Moreover, baseline daily energy expenditure was reduced beyond the level expected from reduced metabolic mass, showing CR could induce metabolic adaptation $[22,29,40]$. This adaptation was shown to be accompanied 
by an increase in leptin levels [41] (although this did not change subjective ratings of appetite [42]). ER also improved metabolic flexibility (i.e., the capacity to adapt fuel oxidation to availability), which in turn improved sensitivity to insulin [43]. Furthermore, the $\mathrm{CR}$ group in the CALERIE trial showed significant improvements in metabolic disease risk factors (C-reactive protein [CRP], insulin sensitivity, and metabolic syndrome score) [44]. CR significantly decreased triiodothyronine levels as well [11], which is interesting as decreased thyroid function is associated with increased longevity in model organisms [45-49] and elderly humans [50-52]. In glucose-resistant overweight to obese patients, ER reduced insulin resistance and insulin-like growth factor 1 (IGF1) levels, [53] but this effect seems only transient [54] and limited to the weight-loss phase-except if accompanied by a reduction in protein intake [55]. This improves glucose tolerance, even though the intervention is modest [36]. Of note, no change in IGF1 (nor growth-hormone (GH)) levels was observed in non-obese volunteers [56]. Moreover, prolonged CR was shown to reduce liver enzymes (alkaline phosphatase and gamma-glutamyl transferase) and to increase levels of circulating bilirubin, all of which correlate with improved liver function [57].

Participants in the CALERIE trial [24] affected to the CR group showed a sustained reduction in all measures of cardiovascular risk (low-density lipoprotein [LDL]/highdensity lipoprotein [HDL] cholesterol ratio, systolic and diastolic blood pressure) [44]. These effects were robust after controlling for weight loss-related changes, once again pointing to a molecular effect of ER beyond simple weight loss. Furthermore, prolonged CR was shown to markedly reduce risk factors for atherosclerosis (total cholesterol, LDL/HDL ratio, triglycerides, fasting glucose and insulin levels, CRP, platelet-derived growth factor $\mathrm{AB})$, translating into a $40 \%$ reduction in carotid artery intima-media thickness [58]. CR was shown as well to improve the sympathetic/parasympathetic nervous system balance (a risk factor of cardiovascular diseases) in overweight individuals [59]. These effects translated to a $30 \%$ reduction of the 10 -year risk of cardiovascular disease [54], confirming earlier projections [60]. In obese patients treated with at least one medication for hyperlipidemia, hypertension, or diabetes, total body fat and cardiometabolic risk factors were reduced by ER without increasing adverse events or lean mass loss [61].

In non-obese humans, $\mathrm{CR}$ reduced whole-body inflammation as measured by circulating markers such as lymphocyte counts, intercellular adhesion molecule-1 (ICAM-1, also known as CD54), serum CRP, tumor necrosis factor-alpha (TNF- $\alpha$ ), [11] and leptin. However, CR had no effect on clinically significant indicators of cell-mediated immunity (such as delayed-type hypersensitivity skin response or antibody vaccine response) [62]. In infectious diseases, fasting-induced metabolism was shown to increase tissue tolerance to bacterial-induced inflammation, but not to viral-induced inflammation [63]. Moreover, prolonged cycles of fasting reverse immunosuppression caused by cytotoxicants [64]. Interestingly, spermidine, a polyamine whose administration mimics $C R$, was able to rescue the formation of the memory $\mathrm{CD} 8^{+} \mathrm{T}$-cell compartment in aged mice [65]. Furthermore, an FMD [10] was shown to increase tumor immunogenicity and tumor-infiltrating lymphocytes, as well as to enhance the number of common lymphoid progenitor cells [66]. These observations are in coherence with previous results in long-lived non-human primates showing that ER reduced T-cell senescence [67]. These results should be considered in perspective with a recent study indicating that T-cell dysfunction in tumors is linked to the cellular distribution of acetyl-coenzyme A (AcCoA), [68] a criterion which is closely linked to ER, as we will see below. An ongoing clinical trial [69] should offer more information about the impact of FMDs on antitumor immunity.

A history of severe ER (due to anorexia nervosa) was shown to strongly reduce the incidence of breast cancer [70]. Such a protective effect of ER is known at least since 1914 [71]. It has been continuously investigated since [72], and there is a strong rationale supporting it [9,73-78]. As abovementioned, ER reduces aging [9,22,28-30], inflammation, [11,62], and metabolic imbalances [36,43,53], all of which are associated with cancer initiation and progression. Further, a higher intake of spermidine was shown in a prospective epidemi- 
ological study to be associated with lower general and cancer-specific mortality $[79,80]$. Despite this strong rationale and preclinical evidence, relatively few clinical investigations on ER in cancer treatment have been completed or are ongoing; most of them investigate FMD regimens [81]. Numerous clinical trials of dietary interventions are underway, with a focus on modifications to the nature of nutritional intake (e.g., ketogenic diet) [81].

There is clinical evidence that short-term fasting (STF) surrounding chemotherapy initiation is well tolerated [82-85] and is even reported to improve QOL and chemotherapyassociated fatigue [86]. Furthermore, STF appears to either reduce DNA damage or promote DNA reparation $[83,84,87]$. A recently published clinical trial [88] showed that stage II/III HER2-negative breast cancer patients benefited from an FMD consisting of a low amino acid short-term ER diet. Specifically, both radiological and pathological responses were statistically more frequent in patients using such an FMD [87]. However, this trial failed to meet its primary endpoint, which was attributed to low patient compliance with the FMD [89]. Most published clinical evidence in the field is from small-sized pilot studies, calling for upscaled evaluations of the effects of STF and CR in combination with standardof-care. Such trials are underway [81,90-92].

Despite their multiple health- and life-span prolonging effects as well as their therapeutic potential in numerous diseases including cancer, patients—and people in general-have difficulties in adhering to calorie-restricting diets $[36,93,94]$. Furthermore, some of the health-promoting effects of ER may be mediated by its cellular consequences rather than weight reduction per se (whole body and cellular effects of ER are recapitulated in Figure 1). This led to the identification of caloric restriction mimetics (CRMs), a class of compounds that recapitulate some biochemical and physiological effects of fasting and CR [95]—in particular autophagy induction [96].
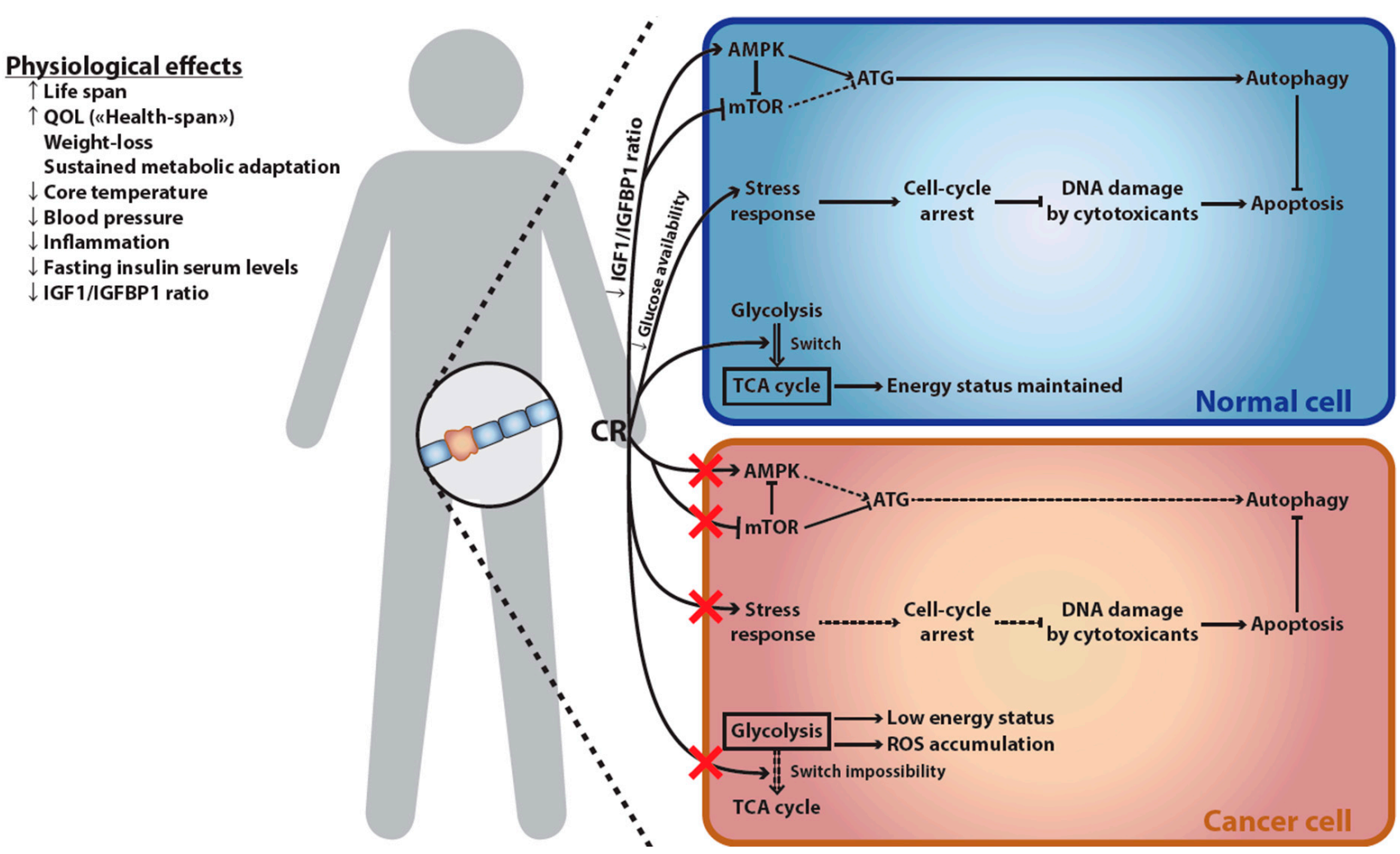

Figure 1. Cellular and physiological effects of ER. Consequences of ER at the physiological level (left) and its differential impact on normal versus cancer cells (right). ER has broad-ranging physiological effects, increasing both lifespan and QOL. This increase in the length and quality of life is strongly associated with ER-induced weight loss and sustained metabolic 
adaptation. The latter results in decreased markers of accelerated senescence, including core-body temperature, blood pressure, inflammation, fasting insulin serum levels, and IGF1/IGFBP1 ratio. This last parameter explains part of ERmediated differential effect on cancer versus healthy cells: decreased IGF1/IGFBP1 ratio up-regulates AMPK, an activator of autophagy, and down-regulates mTOR, an autophagy inhibitor. Autophagy then protects the normal cell against chemotherapy-induced cell death. This cellular switch is not observed in cancer cells, which often have developed independence from the IGF1/IGFBP1 signal. Furthermore, ER reduces circulating glucose levels, which induces a cell-cycle arrest, thus protecting cells against chemotherapy-induced DNA damage. Cancer cells are often independent of cellcycle arrest signals, and thus suffer increased DNA damages upon chemotherapeutic treatment. Finally, reduced glucose availability induces a reliance of normal cells on the TCA cycle for maintaining their energy status. This is not possible in most cancer cells, which rely on glycolysis to fuel their growth ("Warburg effect") and are thus deprived of energy. As increased oxygen consumption fails to produce ATP, this leads to the accumulation of toxic ROS in cancer cells, an effect which has been referred to as the "anti-Warburg effect". AMPK, AMP-activated protein kinase; ATG, autophagy-related proteins; ER, energy restriction; IGF, insulin-like growth factor; IGFBP, IGF-binding protein; mTOR, mammalian target of rapamycin; QOL, quality of life; ROS, reactive oxygen species; TCA, tricarboxylic acid.

\section{Differential Impact of ER on Healthy versus Cancer Cells}

It has been known for more than a decade that starvation protects normal but not transformed cells against chemotherapeutics and oxidative damage, in yeasts, cell cultures, and mice $[97,98]$. This effect has been observed in several malignancies [99] such as colon carcinomas [100], melanomas [101], gliomas [101,102], and breast cancers [66,103]. Such phenomenon has been dubbed "differential stress resistance" (DSR; sometimes referred to as "differential stress sensitization" [99]). Proposed molecular mechanisms for DSR are recapitulated in Figure 1. DSR likely originates from the independence of malignant cells from growth signals and their insensitivity to anti-growth signals $[97,104]$; two hallmarks of cancer described by Hanahan and Weinberg $[105,106]$. These characteristics result from oncogenic gain-of-function mutations affecting the activity of AKT, mechanistic target of rapamycin (mTOR), RAS, and other pro-proliferative signaling factors, and/or of loss-offunction mutations in genes encoding tumor suppressors such as TP53. Consequently, cancer cells are unable to adapt to the lack of nutrients and maintain a sustained proliferation. On the contrary, normal cells switch to a maintenance program conferring resistance to stress. Fasting for $72 \mathrm{~h}$ protected melanoma and glioma-bearing mice against the toxicity associated with high-dose chemotherapy. This beneficial effect was mediated through a $70 \%$ decrease of the level of circulating IGF1, and a concomitant 11-fold increase of the plasmatic level of its inhibitor, insulin-like growth factor-binding protein 1 (IGFBP-1) [101]. Furthermore, ER reduces available glucose, which may affect cancer cells relying on glycolysis [107] (i.e., the "Warburg effect") more than quiescent normal cells and reduces glycosylation of proteins [108]. On top of glucose restriction which bears more heavily on glycolysis-dependent cancer cells, STF was shown to increase oxygen consumption in cancer cells while failing to produce ATP through the respiratory chain. This phenomenon, termed the "anti-Warburg effect", leads to the accumulation of reactive oxygen species, cellular damage, and sensitization of cancer cells to apoptosis upon exposure to chemotherapeutic agents [109]. Reduced protein glycosylation increases protein misfolding, which is handled through the unfolded protein response (UPR). As UPR is already upregulated in most cancer cells but not normal cells [110], this may prove an additional differential stressor of cancer cells. Finally, Valter Longo's team has shown that heme oxygenase-1 (HO-1) acts as a critical mediator of the DSR. Upon FMD/STF, HO-1 expression increased in normal tissues but decreased in breast tumors. This reduction of HO-1 sensitized malignant cells in vitro and mammary murine tumors in vivo to chemotherapy. Accordingly, the overexpression of HO-1 appeared sufficient to impair treatment efficacy [66].

One of the knock-on effects of ER is autophagy induction, which is triggered in response to cellular stress such as DNA damage, ER or mitochondrial stress, oxidative or metabolic stress [111]. In cancer cells, autophagic activity helps to survive in the hypoxic and nutrient-deprived tumor microenvironment and has also been described as a drug resistance mechanism. Somewhat counter-intuitively, this knock-on autophagy 
induction is not detrimental to the general antitumoral effect of ER and helps explain DSR. As we have seen, cancer cells are more sensitive to metabolic stresses and, as we know, they are also more sensitive to genotoxic stress than most somatic cells. Thus, the concomitant amplification of these two stresses thanks to ER and chemotherapy can prove fatal to malignant cells, whereas ER-induced autophagy probably contributes to its observed protective effect against chemotherapy in healthy cells. Moreover, and perhaps most importantly, cellular stress and autophagy contribute to tumor immunogenicity. Therefore, their co-stimulation by cytotoxic drugs plus ER further promotes the invasion of the neoplastic microenvironment by dendritic cells [112], and in turn the initiation or reinstatement of cancer immunosurveillance [113-115].

\section{Molecular and Cellular Signature of ER}

Autophagy was first described in 1957 by Clarck [116], with the term being coined in 1963 by de Duve [117], and the associated machinery being elucidated in 1993 [118], for which Pr. Ohsumi was awarded the 2016 Nobel Prize in Physiology and Medicine [119]. Several types of autophagy have been identified [120], with the main one being macroautophagy (which will be referred to as "autophagy" for the scope of this review). Autophagy is a conserved mechanism that can both maintain cellular homeostasis by recycling dysfunctional organelles or proteins (including aggregates) from the cytoplasm [121] and regulate the cell's energy stocks by converting macromolecules into energy-rich substrates [122]. Autophagy is also involved in redistributing key macronutrients but also ions such as iron [123], zinc [124], or potassium [125]. The interest of autophagy induction in the treatment of cancers is a hotly debated subject [126], with the consensus tending towards a benefit [127], particularly in light of its relationship to immunogenic cell death [128] (ICD), a concept which is discussed below.

Protein acetylation usually inhibits autophagy whereas protein deacetylation promotes autophagy. Mechanistically, in nutrient-rich conditions, mTORC1 (mTOR complex 1) phosphorylates and thus activates the protein acetyl transferase p300. In turn, phosphorylated p300 acetylates autophagy proteins ATG5 and ATG7, thus inhibiting autophagosome formation. Furthermore, p300 acetylates nuclear LC3 (microtubule-associated protein 1A/1B-light chain 3; known as ATG8 in yeasts), which impairs its interaction with DOR (diabetes and obesity-regulated gene) required for its export to the cytoplasm, and thus prevents its cytoplasmic interaction with ATG7 to promote autophagy. Conversely, starvation conditions stimulate deacetylation of ATG5, ATG7, and LC3 by sirtuins (SIRTs) $[129,130]$. The starvation of the amino acid leucine induces autophagy by a reduction of acetyl coenzyme A, thus inhibiting the p300-mediated acetylation of raptor, a component of mTORC1, and resulting in mTORC1 inhibition [131,132]. This points to intimate crosstalk between the two nutrient sensors EP300 and mTORC1.

Protein acetylation is regulated by acetyltransferases and deacetylases, as well as the availability of intracellular AcCoA. The so-called "master regulator" mTOR is implicated in numerous cellular processes and diseases, notably cancer [133]. mTOR is a key repressor of autophagy [134] both directly and by activating lysine acetyltransferases (KATs). mTOR is under the control of insulin and IGF1 through the phosphoinositide 3-kinase (PI3K)/ protein kinase B (PKB; often referred to as AKT) pathway [135]. As we have seen, ER reduces IGF1 levels [53] (albeit transiently) — thus de-repressing autophagy. Furthermore, ER activates AMP-activated protein kinase (AMPK), a key nutrient sensor whose activity varies with the AMP/ATP ratio [136] (ADP may play a role as well [137]) and thus with nutritional status. Under low nutrient availability, AMPK activation promotes the activation of Ulk1, [138-140] a kinase regulating autophagic activity. Meanwhile, AMPK also inhibits mTOR [141] (and its downstream effectors [142]). Inversely, active mTOR inhibits AMPK-Ulk1 interaction [140]. Furthermore, SIRTs are NAD-dependent lysine deacetylases (KDACs). Under CR, mitochondrial respiration is upregulated and produces more NAD which in turn increases SIRT deacetylase activity [143,144]. It is further hypothesized that in mammals, ER may prevent the aging-associated accumulation of biotin, 
a strong inhibitor of SIRTs [144]. Finally, by reducing nutrients and energy, ER depletes cytosolic AcCoA, thus reducing its availability as a donor of acetyl groups and displacing the equilibrium of protein acetylation.

\section{Identification of CRMs}

Based on the aforementioned biochemical signature of ER, compounds stimulating autophagy through cellular protein deacetylation have been identified and defined as CR mimetics, CRMs (Table 1) $[95,96,145,146]$. Further, the definition of CRMs implies that they must not have significant off-target or knock-on effects on other pathways unrelated to ER.

Three main classes of CRMs can be distinguished depending on their ability to (1) inhibit acetyltransferases (e.g., EP300), (2) activate deacetylases (e.g., SIRT-1 or SIRT-3), or (3) deplete the cytosolic stock of AcCoA (e.g., through inhibition of the ATP citrate lyase (ACLY)). Multiple natural autophagy inducers can modulate the equilibrium of protein acetylation (Table 1) $[95,145]$. For instance, hydroxycitrate (extracted from the plants Garcinia or Hibiscus) and radicicol (produced by the fungus Pochonia chlamydosporia) are well-characterized inhibitors of ACLY [96,147-155]. Garcinol (also found in Garcinia), curcumin (extracted from curcuma), spermidine (a polyamine produced by cells to support proliferation and differentiation, and enriched in some vegetables, cereals, or soy derivatives [156]), as well as anacardic acid (extracted from the shell of the cashew nut) are inhibitors of EP300 [80,157,158]. Besides anacardic acid, other salicylate derivatives like aspirin reduce EP300 activity [159-161]. Moreover, monophenols like caffeic [162-165] and gallic [162,166-169] acids (common in plants) stimulate SIRT activity. The same property has been observed for several subtypes of polyphenols such as the stilbenes resveratrol and piceatannol (found in red wine or tea), or the flavonoids catechin, epicatechin, myricetin, and quercetin (enriched in tea, fruits). Similarly, nicotinamide (also known as vitamin $\mathrm{B} 3 / \mathrm{PP}$ ) and its derivatives (e.g., nicotinamide mononucleotide (NMN), nicotinamide adenine dinucleotide (NAD)) are SIRT activators [170,171]. Additional molecules with the propensity to mimic ER have been chemically synthesized. They include the specific inhibitors of ACLY SB-204990 [172,173], the activators of SIRT1 SRT1720 [174-176] and SRT2104 [177], as well as the inhibitors of EP300 A-485 [178] and c646 [179,180]. Other CRMs decrease the production of AcCoA by reducing the mitochondrial influx of metabolites fueling its synthesis. For instance, perhexilin inhibits carnitine O-palmitoyl transferase 1 (CPT1), thus altering the import of fatty acids from the cytosol $[147,181]$ The synthetic agent UK5099 [182] and CPI-613 [183-185] hinder the activity of the mitochondrial pyruvate carrier (MPC) and pyruvate dehydrogenase (PDH), thus impeding the mitochondrial supply in pyruvate. In addition, the non-cleavable citrate analog, 1,2,3-benzene tricarboxylate, binds to the citrate transport carrier (CTP), prevents the mitochondrial export of citrate, and in turn represses the synthesis of AcCoA [186,187]. Other compounds, like 3,4'-dimethoxychalcone, potentiate the autophagic flux and decrease the acetylation profile of nucleo-cytosolic proteins through metabolic mechanisms that remain to be determined [188,189],

Table 1. Some non-toxic compounds inducing autophagy through protein deacetylation and referred to as CRMs.

\begin{tabular}{|c|c|c|}
\hline CRM & Target(s) & Reference(s) \\
\hline 1,2,3-benzene tricarboxylate & CTP & Cappello et al. [186]; Guay et al. [187] \\
\hline 3,4'-dimethoxychalcone & GATA-1/2, TFEB, TFE3 & Carmona-Guttierez et al. [189] Chen et al. [188] \\
\hline A-485 & EP300 & Lasko et al. [178] \\
\hline Anacardic acid & ЕР300 & $\begin{array}{l}\text { Rajendran et al. [190]; Wu et al. [191]; } \\
\text { Pietrocola et al. [192] }\end{array}$ \\
\hline Aspirin & $\begin{array}{l}\text { AMPK, EP300, COX-1, COX-2, } \\
\text { mTOR, NF-kB }\end{array}$ & Pietrocola, Castoldi, et al. [159-161] \\
\hline
\end{tabular}


Table 1. Cont.

\begin{tabular}{ccc}
\hline CRM & Target(s) & Reference(s) \\
\hline C646 & EP300 & Mariño et al. [179]; Liu et al. [180] \\
\hline $\begin{array}{c}\text { Caffeic acid; Caffeic acid ethanol } \\
\text { amide; Caffeic acid phenethyl ester }\end{array}$ & $\begin{array}{c}\text { AMPK, Sirtuins (notably } \\
\text { SIRT1 and SIRT3) }\end{array}$ & $\begin{array}{c}\text { Pietrocola et al. [162]; Lee et al. [163]; } \\
\text { Treviño-Saldaña \& Garcia-Rivas [164]; } \\
\text { Murtaza et al. [165] }\end{array}$ \\
\hline Catechin & Unknown & Chung et al. [193]; Pietrocola et al. [162] \\
\hline $\begin{array}{c}\text { CPI-613 (lipoate analog) } \\
\text { Cyclopentylidene-[4-(4- } \\
\text { chlorophenyl)thiazol-2-yl)hydrazone } \\
\text { (CPTH-2) }\end{array}$ & PDH & Stuart et al. [184]; Zachar et al. [183]; Lee et al. [185] \\
\hline
\end{tabular}

Kubota et al. [196]; Shakibaei et al. [197]; Ryu et al.

[198]; Suckow \& Suckow [199]; Liao et al. [200]; Seo et al. [201]; Sharma et al. [202]; Rao et al. [203];

Curcumin $\quad$ AMPK, mTOR, EP300

Huang et al. [204]; Bimonte et al. [205];

Balasubramanyam et al. [206]; Neckers et al. [207];

Morimoto et al. [208]; Sunagawa et al. [209]; Kang

et al. [210]; Chung et al. [193]; Pietrocola et al. [192]

\begin{tabular}{|c|c|c|}
\hline Epigallocatechin-3-gallate (EGCG) & AMPK, mTOR, HATs, KDACs & Chen et al. [211]; Jang et al. [212]; Niu et al. [213] \\
\hline Epicatechin & Unknown & Chung et al. [193]; Pietrocola et al. [162] \\
\hline Gallic acid & AMPK and HATs & $\begin{array}{l}\text { Jara et al. [166]; Lu et al. [167]; Kim et al. [168]; } \\
\text { Quideau et al. [169]; Pietrocola et al. [162] }\end{array}$ \\
\hline Garcinol & EP300 & $\begin{array}{c}\text { Chen et al. [157]; Li et al. [214]; Arif et al. [215]; } \\
\text { Pietrocola et al. [192] }\end{array}$ \\
\hline Hydroxycitric acid & ACLY & $\begin{array}{l}\text { Phan et al. [147]; Hanai et al. [148]; Asghar et al. } \\
\text { [149]; Onakpoya et al. [150]; Mariño et al. [179] }\end{array}$ \\
\hline MB-3 & HATs & Mai et al. [194] \\
\hline Myricetin & SIRT1 & Pietrocola et al. [162] \\
\hline $\begin{array}{l}\text { Nicotinamide and derivatives (NAD+; } \\
\text { nicotinamide mononucleotide; } \\
\text { nicotinamide riboside) }\end{array}$ & Sirtuins & Lu et al. [170]; Belenky et al. [171] \\
\hline Perhexiline maleate & CPT1, mTOR & Phan et al. [147]; Abozguia et al. [181] \\
\hline Piceatannol & SIRT1 & $\begin{array}{l}\text { Yum et al. [216]; Kinoshita et al. [217]; Kwon et al. } \\
\text { [218]; Minakawa et al. [219]; Pietrocola et al. [162] }\end{array}$ \\
\hline Quercetin & SIRT1 & $\begin{array}{l}\text { Angst et al. [220]; Pratheeshkumar et al. [221]; Dong } \\
\text { et al. [222]; Chung et al. [193]; Pietrocola et al. [162] }\end{array}$ \\
\hline Radicicol & ACLY, HSP90 & $\begin{array}{l}\text { Zhao et al. [151]; He et al. [152]; Sonoda et al. [153]; } \\
\text { Conte et al. [154]; Griffin et al. [155] }\end{array}$ \\
\hline Resveratrol (SRT501 = micronized resv.) & SIRT1, AMPK, NF-KB & $\begin{array}{l}\text { Timmers et al. [223]; Lissa et al. [224]; Minor et al. } \\
\text { [174]; Pearson et al. [225]; Liu et al. [226]; Fiori et al. } \\
\text { [227]; Hubbard et al. [228]; Park et al. [229]; Chung } \\
\text { et al. [193]; Pietrocola et al. [162]; Milne et al. [175] }\end{array}$ \\
\hline SB-204990 & ACLY & Hatzivassiliou et al. [172]; Pearce et al. [173] \\
\hline Spermidine & EP300, mTOR, AMPK & $\begin{array}{l}\text { Eisenberg et al. [230]; Bauer et al. [231]; Soda et al. } \\
\text { [232]; Matsumoto et al. [233]; Paul \& Kang [234]; } \\
\text { LaRocca et al. [158]; Pietrocola et al. [192] }\end{array}$ \\
\hline SRT1720 & SIRT1 & $\begin{array}{l}\text { Minor et al. [174]; Milne et al. [175]; } \\
\text { Mitchell et al. [176] }\end{array}$ \\
\hline
\end{tabular}


Table 1. Cont.

\begin{tabular}{ccc}
\hline CRM & Target(s) & Reference(s) \\
\hline SRT2104 & SIRT1 & Hoffmann et al. [177] \\
\hline Trientine (TETA) & SAT1 & Pietrocola et al. [235] \\
\hline UK5099 & MPC & Bricker et al. [182] \\
\hline
\end{tabular}

Abbreviations. ACLY, adenylate citrate lyase; AMPK, adenosine monophosphate-activated protein kinase; COX, cyclooxygenase; CPT1, carnitine O-palmitoyl transferase 1; CRMs, caloric restriction mimetics; CTP, mitochondrial citrate transport carrier; EP300, Histone acetyltransferase p300; GATA, transcription factor of the GATA-motif binding zinc-finger protein family; HAT, histone acetyltransferase; HSP, heat-shock protein; KDAC, lysine deacetylase; MPC, mitochondrial pyruvate carrier; mTOR, mammalian target of rapamycin; NAD, nicotinamide adenine dinucleotide; PDH, pyruvate dehydrogenase; SIRT, sirtuin; TFE3, transcription factor E3; TFEB, transcription factor EB.

\section{ER as an Adjuvant to Cancer Immunotherapy}

As abovementioned, ER may be useful in the treatment of cancer, especially in combination with ICD-inducing therapies. Furthermore, the impact of fasting, $C R$, and their mimetics on tumor growth is at least partly immune-mediated. This begs the question of their application as an adjuvant to cancer immunotherapies. We recapitulate existing preclinical evidence of such combinations in Table 2. When screening the literature, we have to be mindful of publication bias (i.e., positive results are more likely to be published than negative results). However, as congruent results are reported with several different immunotherapies and ER regimens, we believe the available evidence generally confirms the interest of ER as an adjuvant to most types of cancer immunotherapies.

Table 2. Reported regimens associating ER to immunotherapies in preclinical studies.

\begin{tabular}{cccccc}
\hline Type of Immunotherapy & Therapeutic Agent & Fasting & FMD & CR & CRM \\
\hline \multirow{3}{*}{ Immune checkpoint modulators } & Anti-PD-1 & {$[236]$} & - & - & {$[236]$} \\
& Anti-PD-L1 & - & - & - & {$[237]$} \\
\cline { 2 - 5 } & Anti-TNFRSF4 & - & - & {$[238]$} & {$[23]$} \\
\cline { 2 - 5 } Interleukin & IL-2 & - & - & {$[239]$} & - \\
\hline \multirow{3}{*}{ ICD-inducing chemotherapies } & Cyclophosphamide & {$[66,101]$} & {$[66]$} & - & - \\
\cline { 2 - 5 } & Doxorubicin & {$[66,101]$} & {$[66]$} & - \\
\cline { 2 - 5 } & Mitoxantrone & {$[113,236]$} & - & - & {$[113,236]$} \\
\cline { 2 - 5 } & Tyrosine kinase inhibitors & {$[109,113,236]$} & - & - & {$[113,236]$} \\
\cline { 2 - 5 } & Temozolomide & {$[102]$} & - & - & - \\
\hline \multirow{2}{*}{ Oncolytic viruses } & Measles virus & {$[242]$} & - & - & - \\
\cline { 2 - 5 } & Herpes simplex virus & {$[243]$} & - & - \\
\hline
\end{tabular}

Cells indicate the references of the articles reporting the corresponding combinations together with the presence or absence of reported antitumor efficacy in green or red, respectively. CR, caloric restriction; ER, energy restriction; FMD, fasting-mimicking diet; ICD, immunogenic cell death; IL, interleukin. PD-1, programmed cell death 1; PD-L1, programmed cell death ligand 1; TNFRSF4, tumor necrosis factor receptor superfamily, member 4 .

It is known since 1977 that some chemotherapies can stimulate the cytotoxic activity of immune cells in vitro, [244] which was confirmed in cancer patients in 1986 [245]. Nevertheless, chemotherapy-induced cell death (typically apoptosis) was largely considered tolerogenic or immunosuppressive, or at the very least null from the immune standpoint [246]. The concept of immunogenic cell death (ICD) emerged in the mid-2000s [247], challenging this view. In particular, our group demonstrated how tumor-specific immune responses determined the efficacy of some conventional cytotoxic chemotherapies [248], one reason for considering such cytotoxic agents as immunotherapies. Since this initial discovery, ICD has been widely studied and its mechanisms ascertained [249]. Broadly, pre-mortem endoplasmic reticulum stress $[250,251]$ and autophagic activity [112] induce exposure of calreticulin $[252,253]$ (CALR) on the surface of the plasma membrane during the pre-apoptotic stage, and ATP secretion [112] as well as the release of the nuclear protein high-mobility group box 1 (HMGB1) and the cytosolic protein annexin1 (ANXA1) during secondary necrosis [254]. In turn, ATP helps to recruit dendritic cells (DC) to the tumor 
bed [255]. ANXA1 binds formyl peptide receptor 1 (FPR1) thus facilitating DC homing to dying cells in the tumor bed, [256] and CALR stimulates tumor antigen engulfment by DCs [257]. HMGB1 then promotes activation of DCs [258]. All in all, this results in a strong interferon- $\gamma$-mediated immune response mainly involving cytotoxic CD8 ${ }^{+} \mathrm{T}$-cells [259]that is, immunosurveillance is reinstated. Furthermore, ICD induces a type- 1 interferon response (probably through PRR sensing of the nucleic acids released from dying cells), which contributes to T-cell priming [260]. ICD status of chemotherapeutics is given growing attention in clinical practice, especially when it relates to combinations with immune checkpoints inhibitors (ICIs) [261].

Numerous cancer therapies currently used or under development are ICD inducers [262]. For instance, radiotherapy [263] is inducing ICD in an autophagy-dependent manner, [264] as are several chemotherapies: "classical" cytotoxic agents such as doxorubicin, [265] cyclophosphamide, [266,267] or oxaliplatin; [268,269] but also "targeted" therapies like crizotinib [270]. Interestingly, some combinations of non-ICD-inducing cytotoxic agents can result in the promotion of ICD, as is the case with carboplatin + pemetrexed bitherapy [271]. As a side note, cardiac glycosides exert an anticancer effect through ICD induction [272]. Interestingly, ICD can also be induced in cancer cells by physical means such as high hydrostatic pressure [273] or photodynamic therapy [253,274]. Other therapeutic approaches like oncolytic viruses [275] can precipitate ICD. Such effect was demonstrated with both RNA viruses such as the coxsackievirus B3 [276] or measles virus [277], and DNA viruses such as oncolytic adenoviruses [278,279] or herpes simplex viruses (HSV) [280]. Association of the latter with chemotherapeutic intervention even potentiated the immunogenicity of cancer cell death [281]. Additionally, an oncolytic peptide, namely LTX-315-displayed ICD-inducing properties as shown in vitro [282] and corroborated by preliminary clinical observations [283,284].

As we have seen, ICD induction is mostly autophagy-dependent, with autophagy contributing to ATP secretion and thus to DC recruitment, [112] a critical step for mediating an adaptive antitumor immune response. This has led several authors to propose the use of ER to further stimulate autophagy upon treatment with ICD-inducing therapeutic regimens; a hypothesis since validated by multiple preclinical investigations. For example, fasting synergizes in vitro with tyrosine kinase inhibitors (TKIs) like crizotinib [240,241] (which induces ICD [270]) and others [240] for the inhibition of tumor growth. Furthermore, fasting enhances the response of both radio- and chemo-therapy (temozolomide) on glioma models in mice [102]. Of note, standard clinical practice is to administer temozolomide in a fasted state. Our team has shown [113] that this synergistic effect of fasting on chemotherapies could be recapitulated by CRMs. The benefit of these ER interventions resulted from an enhanced infiltration of the tumor bed by activated $\mathrm{CD}^{+} \mathrm{T}$ cells, together with a concomitant reduction of regulatory $\mathrm{CD}^{+} \mathrm{T}$ lymphocytes from the tumor bed [113]. Further work has confirmed a critical involvement of $\mathrm{CD} 11 \mathrm{~b}^{+}$myeloid cells and in particular an ER-induced enrichment in mature monocyte-derived DCs [236].

As treatment with cytotoxic agents increased expression of immunosuppressive programmed cell-death 1 (PD-1) and its ligand (PD-L1) on cancer or immune cells, we evaluated a triple combination of a CRM + an ICD-inducing chemotherapy + an anti-PD1 antibody. This tritherapy led to the complete cure of most tumor-bearing mice [236]. Combination regimens of ICIs with ER ought to be explored further. In this line, an interesting article [237] has recently reported that CRM resveratrol promoted abnormal glycosylation of PD-L1 and thus its endoplasmic retention. Consequently, cancer cells exposed to resveratrol demonstrated enhanced sensitivity to T cell-mediated killing. Another recent study [285] showed deacetylation-dependent translocation of PD-L1 from the cell membrane to the nucleus. There, PD-L1 bound to DNA and promoted the expression of genes related to antigen presentation and inflammation, but also of other immune checkpoints such as V-domain immunoglobulin suppressor of T cell activation (VISTA) and PD-L2. Although the exact consequences of membrane PD-L1 deacetylation remain unclear [286], these results provide further evidence of a likely positive interaction between ER and ICB. 
Generally, the combination of fasting, CR, or their mimetics with immunotherapies has been somewhat understudied so far, given the strong rationale supporting this approach. For example, treatment with interleukin-2 (IL-2) is a long-existing immunotherapeutic approach to melanoma and metastatic renal cell carcinoma [287]. ER was shown by one team in the 1980's as promoting thymocyte proliferation in response to exogenous IL-2 in autoimmune-prone mice [239]. Yet, associations of ER and IL-2 do not seem to have been studied since.

Oncolytic virotherapy is considered a promising strategy for cancer treatment, [288] as it causes both targeted cytotoxicity and anticancer immune responses. Regrettably, few publications have investigated combinations of ER with oncolytic virotherapy. However, recent evidence [243] has emerged that transient fasting increased the replication and glioblastoma-specific cytotoxicity of herpes simplex virus (HSV), which is being engineered as an oncolytic virus, but did not stimulate HSV-induced killing of normal astrocytes. This differential effect was convincingly explained by the authors by depressed protein synthesis upon fasting (mediated by increased phosphorylation of the translation initiation factor eIF2 $\alpha$ ) in normal cells but not cancer cells. Even more recent evidence [242] has emerged in favor of a similar positive effect of fasting on the efficacy of an oncolytic measles vaccine on colorectal cancer cells. However, the effect of autophagy on replication and immunogenicity seems to differ, depending on the virus $[289,290]$. It is tempting to speculate that current nutrient-rich cell culture practices do not reflect the specific metabolic profile of the tumoral microenvironment. Thus, high-glucose, high glutamine media may skew in vitro studies of oncolytic viruses by providing metabolic conditions which favor (or hinder) viral replication/cytotoxicity but that are not available in the tumor microenvironment [291].

Some active fields of immunotherapeutic research have not yet been evaluated with respect to possible combinations with CR. Cancer vaccines have recently garnered renewed interest [292]. Unfortunately, there is no reported evidence of a combination of ER with any established cancer vaccine, despite evidence that ER promotes memory T cell function [293] and that the efficacy of a vaccine based on a sarcoma cell lysate could be increased in an autophagy-dependent fashion [294]. Adoptive cell transfer is another active field of cancer research, [295] with recent clinical successes. Yet, no combination with ER has been reported, despite recent reports [68] that tumor-infiltrating lymphocytes enter an autophagy-induced adaptive stem-like state which helps in maintaining their anti-tumor potential. This effect could in particular be manipulated (notably by CR) to maintain replicative potential in the case of autologous cell transfer [296]. Finally, there are no reports of combinations of ER with oncolytic peptides.

\section{Ongoing/Reported Clinical Investigations on the Topic}

Ongoing and reported clinical investigations combining ER with immunotherapeutic approaches are reported in Table 3. In most ongoing trials, an ICD-inducing chemotherapeutic agent is induced. The ER arm of the trial mostly consists of an FMD, which involves reduced caloric intake with a qualitative change in diet, usually an increase in the proportion of fats (i.e., a "ketogenic diet") or a restrictive feeding schedule (i.e., "intermittent fasting"). We believe these regimens to be sub-optimal for cancer patients as the reduced energy intake can be difficult to sustain, both psychologically and physiologically. By contrast, CRMs recapitulate ER biochemical effects while allowing for ad libitum feeding. Therefore, CRMs offer two advantages: (i) they do not compromise the nutritional status of cancer patients, who are often at risk of cachexia, and (ii) they are psychologically easier to tolerate and hence ensure better treatment adherence. At last, ER is being explored in two ongoing trials as a single agent, which will allow the evaluation of its specific (i.e., not as part of a combination) contribution to clinical outcomes (Table 3). 


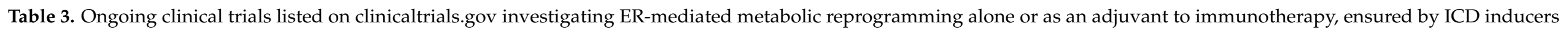
and/or ICIs.

\begin{tabular}{|c|c|c|c|c|c|}
\hline $\begin{array}{c}\text { Type of Combination } \\
\text { Treatment }\end{array}$ & Cancer Type & ICD Inducer & ICI & ER & Reference \\
\hline \multirow[t]{2}{*}{ ER } & Breast; Melanoma & - & - & $\begin{array}{l}\text { FMD (5 days), for } 1 \text { or } 4 \text { four-weeks } \\
\text { cycle(s) }\end{array}$ & NCT03454282 \\
\hline & Glioma & - & - & Fasting $(72 \mathrm{~h})$ & NCT04461938 \\
\hline \multirow{4}{*}{$\begin{array}{l}\mathrm{ER}+\mathrm{ICD} \\
\text { inducer }\end{array}$} & Glioblastoma & Radiotherapy [263] & - & $\begin{array}{l}\text { CR with ketogenic diet }(72 \mathrm{~h}) \text {, followed } \\
\text { by fasting }(72 \mathrm{~h}) \text {, ultimately followed by } \\
\text { another } \mathrm{CR} \text { with ketogenic diet }(72 \mathrm{~h})\end{array}$ & $\begin{array}{l}\text { NCT01754350; Voss } \\
\text { et al. [297] }\end{array}$ \\
\hline & Breast & Radiotherapy [263] & - & $\begin{array}{l}25 \% \mathrm{CR} \text { from } \mathrm{W}-2 \text { to } \mathrm{W}+2 \text { of a } 6 \text { week } \\
\text { radiation therapy regimen) }\end{array}$ & NCT01819233; [299] \\
\hline & Breast & $\begin{array}{c}\text { Doxorubicin }[265]+ \\
\text { cyclophosphamide }[266,267]\end{array}$ & - & Short-term FMD & $\begin{array}{l}\text { NCT02126449; BOOG } \\
\text { group [87] }\end{array}$ \\
\hline & Lung & $\begin{array}{l}\text { Cisplatin/carboplatin }+ \\
\text { pemetrexed [271] }\end{array}$ & - & $\begin{array}{l}\text { Metformin (1500 mg/day) +/- FMD (5 } \\
\text { days every } 3 \text { weeks for } 4 \text { cycles) }\end{array}$ & NCT03709147 \\
\hline $\mathrm{ER}+\mathrm{ICI}$ & Skin & - & PD(L)-1 inhibitors & $\begin{array}{l}\text { Fasting ( } 48 \mathrm{~h} \text { before treatment and } 24 \mathrm{~h} \\
\text { after), for up to } 3 \text { three-weeks cycles }\end{array}$ & NCT04387084 \\
\hline $\begin{array}{c}\mathrm{ER}+\mathrm{ICD} \\
\text { inducer + ICI }\end{array}$ & NSCLC & Carboplatin + pemetrexed [271] & Pembrolizumab & FMD (from D-3 to D + 1 for 4 cycles) & NCT03700437 \\
\hline
\end{tabular}

ER, energy reduction; ICD, immunogenic cell death; ICI, immune checkpoint inhibitor. 


\section{Conclusions}

ER has a differential effect on cancer and healthy cells, a process named "differential stress resistance". This effect is mediated in part by the different metabolic requirements of cancer and healthy cells, but also—and perhaps chiefly—by the cellular effects of ER, especially as it pertains to autophagy.

We have known for a few years that autophagy promotes (i) cancer cell immunogenicity, (ii) tumor-bed immune infiltration, and (iii) depletion of tumor-infiltrating regulatory $\mathrm{T}$ cells, especially when autophagy is induced at the same time as ICD-inducing agents are administered. Interestingly, autophagy induction can be mimicked pharmacologically using CRMs. These mimetics recapitulate the anticancer immune effects of ER and synergize with a combinatorial treatment composed of ICD inducers and a PD-1 blockade to provoke complete tumor regression in a murine model of fibrosarcoma.

Recent work by Vodnala et al. [68] has shed further light on the relationship of CR with immunity in the context of cancer by showing how a calorie-restricted state promotes T-cell stemness and helps in maintaining cancer immunosurveillance. This is especially interesting considering older work by Puleston et al. [65] showing the central role of autophagy in the formation of memory $\mathrm{T} \mathrm{CD} 8^{+}$cells.

These works and others all point towards an immune mechanism that explains the capacity of ER to prevent-and probably event to treat—cancer. This has led us and others to propose ER as an adjuvant to immunotherapy, especially as ER is relatively well tolerated. We can thus only regret the relative lack of published work on such combinations, despite globally positive results in reported experiments. It is our hope that these issues will be addressed by ongoing clinical trials as well as by preclinical research on combinations of ER with certain immunotherapeutic approaches, and especially ICIs, oncolytic viruses, and cancer vaccines.

Author Contributions: E.E. and J.G.P. conceptualized and wrote the manuscript. J.P. made the figure. G.K. edited the manuscript. All authors have read and agreed to the published version of the manuscript.

Funding: G.K. is supported by the Ligue contre le Cancer (équipe labellisée); Agence National de la Recherche (ANR) - Projets blancs; ANR under the frame of E-Rare-2, the ERA-Net for Research on Rare Diseases; Association pour la recherche sur le cancer (ARC); Cancéropôle Ile-de-France; Chancellerie des universités de Paris (Legs Poix), Fondation pour la Recherche Médicale (FRM); a donation by Elior; European Research Area Network on Cardiovascular Diseases (ERA-CVD, MINOTAUR); Gustave Roussy Odyssea, the European Union Horizon 2020 Project Oncobiome; Fondation Carrefour; High-end Foreign Expert Program in China (GDW20171100085 and GDW20181100051), Institut National du Cancer (INCa); Inserm (HTE); Institut Universitaire de France; LeDucq Foundation; the LabEx Immuno-Oncology; the RHU Torino Lumière; the Seerave Foundation; the SIRIC Stratified Oncology Cell DNA Repair and Tumor Immune Elimination (SOCRATE); and the SIRIC Cancer Research and Personalized Medicine (CARPEM). JGP is supported by the SIRIC Cancer Research and Personalized Medicine (CARPEM), the French Society of Hepatology (AFEF), and $l^{\prime}$ Institut thématique multiorganisme (ITMO) Cancer of the Alliance nationale pour les sciences de la vie et de la santé (Aviesan).

Conflicts of Interest: E.E. and G.K. are co-founders of Therafast Bio, a company that develops caloric restriction mimetics for the treatment of cancer. E.E. holds baskets of securities from pharmaceutical companies, some of which develop or hold compounds for the treatment of cancer. G.K. is the scientific co-founder of Samsara Therapeutics, a company that develops novel pharmacological autophagy inducers. G.K. consults for The Longevity Labs, a company that develops natural food extracts. G.K. and J.G.P. are inventors of patents on the use of CRMs for improving cancer immunotherapy. J.G.P. is named as an inventor on patents for cancer vaccination involving an oncolytic rhabdovirus. These patents have been licensed to Turnstone Biologics, of which J.G.P. is a shareholder. 


\section{References}

1. López-Otín, C.; Kroemer, G. Hallmarks of Health. Cell 2021, 184, 33-63. [CrossRef] [PubMed]

2. Colman, R.J.; Anderson, R.M.; Johnson, S.C.; Kastman, E.K.; Kosmatka, K.J.; Beasley, T.M.; Allison, D.B.; Cruzen, C.; Simmons, H.A.; Kemnitz, J.W.; et al. Caloric Restriction Delays Disease Onset and Mortality in Rhesus Monkeys. Science 2009, 325, $201-204$. [CrossRef] [PubMed]

3. Mattison, J.A.; Roth, G.S.; Beasley, T.M.; Tilmont, E.M.; Handy, A.M.; Herbert, R.L.; Longo, D.L.; Allison, D.B.; Young, J.E.; Bryant, M.; et al. Impact of caloric restriction on health and survival in rhesus monkeys from the NIA study. Nature 2012, 489, 318-321. [CrossRef] [PubMed]

4. Colman, R.J.; Beasley, T.M.; Kemnitz, J.W.; Johnson, S.C.; Weindruch, R.; Anderson, R.M. Caloric restriction reduces age-related and all-cause mortality in rhesus monkeys. Nat. Commun. 2014, 5, 3557. [CrossRef] [PubMed]

5. Pifferi, F.; Terrien, J.; Marchal, J.; Dal-Pan, A.; Djelti, F.; Hardy, I.; Chahory, S.; Cordonnier, N.; Desquilbet, L.; Hurion, M.; et al. Caloric restriction increases lifespan but affects brain integrity in grey mouse lemur primates. Commun. Biol. 2018, 1, 30. [CrossRef]

6. Libert, S.V.; Guarente, L.P. Metabolic and Neuropsychiatric Effects of Calorie Restriction and Sirtuins. Annu. Rev. Physiol. 2013, 75, 669-684. [CrossRef]

7. Rubinsztein, D.C.; Mariño, G.; Kroemer, G. Autophagy and Aging. Cell 2011, 146, 682-695. [CrossRef]

8. Fontana, L.; Partridge, L.; Longo, V.D. Extending Healthy Life Span-From Yeast to Humans. Science 2010, 328, 321-326. [CrossRef] [PubMed]

9. Brandhorst, S.; Longo, V.D. Fasting and Caloric Restriction in Cancer Prevention and Treatment. Methods Mol. Biol. 2016, 207, 241-266. [CrossRef]

10. Brandhorst, S.; Choi, I.Y.; Wei, M.; Cheng, C.W.; Sedrakyan, S.; Navarrete, G.; Dubeau, L.; Yap, L.P.; Park, R.; Vinciguerra, M.; et al. A Periodic Diet that Mimics Fasting Promotes Multi-System Regeneration, Enhanced Cognitive Performance, and Healthspan. Cell Metab. 2015, 22, 86-99. [CrossRef] [PubMed]

11. Ravussin, E.; Redman, L.M.; Rochon, J.; Das, S.K.; Fontana, L.; Kraus, W.E.; Romashkan, S.; Williamson, D.A.; Meydani, S.N.; Villareal, D.T.; et al. A 2-Year Randomized Controlled Trial of Human Caloric Restriction: Feasibility and Effects on Predictors of Health Span and Longevity. J. Gerontol. Ser. A Boil. Sci. Med. Sci. 2015, 70, 1097-1104. [CrossRef]

12. Renehan, A.G.; Zwahlen, M.; Minder, C.; O'Dwyer, S.T.; Shalet, S.M.; Egger, M. Insulin-like growth factor (IGF)-I, IGF binding protein-3, and cancer risk: Systematic review and meta-regression analysis. Lancet 2004, 363, 1346-1353. [CrossRef]

13. Walford, R.L.; Mock, D.; Verdery, R.; Maccallum, T. Calorie Restriction in Biosphere 2: Alterations in Physiologic, Hematologic, Hormonal, and Biochemical Parameters in Humans Restricted for a 2-Year Period. J. Gerontol. Ser. A Boil. Sci. Med. Sci. 2002, 57, B211-B224. [CrossRef] [PubMed]

14. Mercken, E.M.; Carboneau, B.A.; Krzysik-Walker, S.M.; de Cabo, R. Of mice and men: The benefits of caloric restriction, exercise, and mimetics. Ageing Res. Rev. 2012, 11, 390-398. [CrossRef] [PubMed]

15. Longo, V.D.; Mattson, M.P. Fasting: Molecular Mechanisms and Clinical Applications. Cell Metab. 2014, 19, 181-192. [CrossRef] [PubMed]

16. Trepanowski, J.F.; Kroeger, C.M.; Barnosky, A.; Klempel, M.C.; Bhutani, S.; Hoddy, K.K.; Gabel, K.; Freels, S.; Rigdon, J.; Rood, J.; et al. Effect of Alternate-Day Fasting on Weight Loss, Weight Maintenance, and Cardioprotection Among Metabolically Healthy Obese Adults. JAMA Intern. Med. 2017, 177, 930-938. [CrossRef]

17. Bales, C.W.; Kraus, W.E. Caloric Restriction. J. Cardiopulm. Rehabil. Prev. 2013, 33, 201-208. [CrossRef]

18. Willcox, B.J.; Willcox, D.C. Caloric restriction, caloric restriction mimetics, and healthy aging in Okinawa. Curr. Opin. Clin. Nutr. Metab. Care 2013, 17, 51-58. [CrossRef]

19. CALERIE (PBRC, Baton Rouge)-Comprehensive Assessment of Long-Term Effects of Reducing Intake of Energy. Available online: https:/ / www.clinicaltrials.gov / ct2/show / NCT00099151 (accessed on 24 October 2020).

20. CALERIE (Washington University): Comprehensive Assessment of Long-term Effects of Reducing Intake of Energy. Available online: https: / / clinicaltrials.gov/ct2/show / NCT00099138 (accessed on 24 October 2020).

21. CALERIE (Tufts)-Comprehensive Assessment of Long-Term Effects of Reducing Intake of Energy. Available online: https: / / www.clinicaltrials.gov / ct2/show / NCT00099099 (accessed on 24 October 2020).

22. Heilbronn, L.K.; De Jonge, L.; Frisard, M.I.; Delany, J.P.; Larson-Meyer, D.E.; Rood, J.; Nguyen, T.; Martin, C.K.; Volaufova, J.; Most, M.M.; et al. Effect of 6-Month Calorie Restriction on Biomarkers of Longevity, Metabolic Adaptation, and Oxidative Stress in Overweight Individuals. JAMA 2006, 295, 1539-1548. [CrossRef]

23. Tam, C.S.; Frost, E.A.; Xie, W.; Rood, J.; Ravussin, E.; Redman, L.M. No Effect of Caloric Restriction on Salivary Cortisol Levels in Overweight Men and Women. Metabolism 2014, 63, 194-198. [CrossRef]

24. CALERIE: Comprehensive Assessment of Long-Term Effects of Reducing Intake of Energy. Available online: https://www. clinicaltrials.gov / ct2/show / NCT00427193 (accessed on 24 October 2020).

25. CALERIE Phase II Ancillary: Metabolic (CALERIE-II). Available online: https:/ / www.clinicaltrials.gov/ct2/show / NCT02695511 (accessed on 24 October 2020).

26. How Participants Behave and Respond on Their Own After Completing a 2-year Intervention of Calorie Restriction (CAL-ERIE2FU). Available online: https:/ / clinicaltrials.gov/ct2/show / NCT00943215 (accessed on 24 October 2020). 
27. Martin, C.K.; Bhapkar, M.; Pittas, A.G.; Pieper, C.F.; Das, S.K.; Williamson, D.A.; Scott, T.; Redman, L.M.; Stein, R.; Gilhooly, C.H.; et al. Effect of Calorie Restriction on Mood, Quality of Life, Sleep, and Sexual Function in Healthy Nonobese Adults. JAMA Intern. Med. 2016, 176, 743-752. [CrossRef] [PubMed]

28. Il'Yasova, D.; Fontana, L.; Bhapkar, M.; Pieper, C.F.; Spasojevic, I.; Redman, L.M.; Das, S.K.; Huffman, K.M.; Kraus, W.E. The CALERIE Study Investigators Effects of 2 years of caloric restriction on oxidative status assessed by urinary F2-isoprostanes: The CALERIE 2 randomized clinical trial. Aging Cell 2018, 17, e12719. [CrossRef]

29. Redman, L.M.; Smith, S.R.; Burton, J.H.; Martin, C.K.; Il'Yasova, D.; Ravussin, E. Metabolic Slowing and Reduced Oxidative Damage with Sustained Caloric Restriction Support the Rate of Living and Oxidative Damage Theories of Aging. Cell Metab. 2018, 27, 805-815.e4. [CrossRef] [PubMed]

30. Belsky, D.W.; Huffman, K.M.; Pieper, C.F.; Shalev, I.; E Kraus, W. Change in the Rate of Biological Aging in Response to Caloric Restriction: CALERIE Biobank Analysis. J. Gerontol. Ser. A Boil. Sci. Med. Sci. 2018, 73, 4-10. [CrossRef] [PubMed]

31. Villareal, D.T.; Fontana, L.; Weiss, E.P.; Racette, S.B.; Steger-May, K.; Schechtman, K.B.; Klein, S.; Holloszy, J.O. Bone Mineral Density Response to Caloric Restriction-Induced Weight Loss or Exercise-Induced Weight Loss. Arch. Intern. Med. 2006, 166, 2502-2510. [CrossRef]

32. Romashkan, S.V.; Das, S.K.; Villareal, D.T.; Ravussin, E.; Redman, L.M.; Rochon, J.; Bhapkar, M.; Kraus, W.E. For the CALERIE Study Group Safety of two-year caloric restriction in non-obese healthy individuals. Oncotarget 2016, 7, 19124-19133. [CrossRef] [PubMed]

33. Racette, S.B.; Rochon, J.; Uhrich, M.L.; Villareal, D.T.; Das, S.K.; Fontana, L.; Bhapkar, M.; Martin, C.K.; Redman, L.M.; Fuss, P.J.; et al. Effects of Two Years of Calorie Restriction on Aerobic Capacity and Muscle Strength. Med. Sci. Sports Exerc. 2017, 49, 2240-2249. [CrossRef] [PubMed]

34. Wei, M.; Brandhorst, S.; Shelehchi, M.; Mirzaei, H.; Cheng, C.W.; Budniak, J.; Groshen, S.; Mack, W.J.; Guen, E.; Di Biase, S.; et al. Fasting-mimicking diet and markers/risk factors for aging, diabetes, cancer, and cardiovascular disease. Sci. Transl. Med. 2017, 9, eaai8700. [CrossRef]

35. Redman, L.M.; Heilbronn, L.K.; Martin, C.K.; Alfonso, A.; Smith, S.R.; Ravussin, E. Pennington CALERIE Team. Effect of Calorie Restriction with or without Exercise on Body Composition and Fat Distribution. J. Clin. Endocrinol. Metab. 2007, 92, 865-872. [CrossRef]

36. Racette, S.B.; Weiss, E.P.; Obert, K.A.; Kohrt, W.M.; Holloszy, J.O. Modest Lifestyle Intervention and Glucose Tolerance in Obese African Americans. Obes. Res. 2001, 9, 348-355. [CrossRef]

37. Sparks, L.M.; Redman, L.M.; Conley, K.E.; Harper, M.-E.; Yi, F.; Hodges, A.; Eroshkin, A.; Costford, S.R.; Gabriel, M.E.; Shook, C.; et al. Effects of 12 months of caloric restriction on muscle mitochondrial function in healthy individuals. J. Clin. Endocrinol. Metab. 2016, 2016-3211. [CrossRef] [PubMed]

38. Das, S.K.; Roberts, S.B.; Bhapkar, M.V.; Villareal, D.T.; Fontana, L.; Martin, C.K.; Racette, S.B.; Fuss, P.J.; Kraus, W.E.; Wong, W.W.; et al. Body-composition changes in the Comprehensive Assessment of Long-term Effects of Reducing Intake of Energy (CALERIE)-2 study: A 2-y randomized controlled trial of calorie restriction in nonobese humans. Am. J. Clin. Nutr. 2017, 105, 913-927. [CrossRef] [PubMed]

39. Marlatt, K.L.; Redman, L.M.; Burton, J.H.; Martin, C.K.; Ravussin, E. Persistence of weight loss and acquired behaviors 2 y after stopping a 2-y calorie restriction intervention. Am. J. Clin. Nutr. 2017, 105, 928-935. [CrossRef] [PubMed]

40. Redman, L.M.; Heilbronn, L.K.; Martin, C.K.; De Jonge, L.; Williamson, D.A.; Delany, J.P.; Ravussin, E. For the Pennington CALERIE Team Metabolic and Behavioral Compensations in Response to Caloric Restriction: Implications for the Maintenance of Weight Loss. PLoS ONE 2009, 4, e4377. [CrossRef] [PubMed]

41. Lecoultre, V.; Ravussin, E.; Redman, L.M. The Fall in Leptin Concentration Is a Major Determinant of the Metabolic Adaptation Induced by Caloric Restriction Independently of the Changes in Leptin Circadian Rhythms. J. Clin. Endocrinol. Metab. 2011, 96, E1512-E1516. [CrossRef]

42. Anton, S.D.; Han, H.; York, E.; Martin, C.K.; Ravussin, E.; Williamson, D.A. Effect of calorie restriction on subjective ratings of appetite. J. Hum. Nutr. Diet. 2009, 22, 141-147. [CrossRef]

43. Huffman, K.M.; Redman, L.M.; Landerman, L.R.; Pieper, C.F.; Stevens, R.D.; Muehlbauer, M.J.; Wenner, B.R.; Bain, J.R.; Kraus, V.B.; Newgard, C.B.; et al. Caloric Restriction Alters the Metabolic Response to a Mixed-Meal: Results from a Randomized, Controlled Trial. PLoS ONE 2012, 7, e28190. [CrossRef]

44. $\quad$ E Kraus, W.; Bhapkar, M.; Huffman, K.M.; Pieper, C.F.; Das, S.K.; Redman, L.M.; Villareal, D.T.; Rochon, J.; Roberts, S.B.; Ravussin, E.; et al. 2 years of calorie restriction and cardiometabolic risk (CALERIE): Exploratory outcomes of a multicentre, phase 2, randomised controlled trial. Lancet Diabetes Endocrinol. 2019, 7, 673-683. [CrossRef]

45. Ooka, H.; Fujita, S.; Yoshimoto, E. Pituitary-thyroid activity and longevity in neonatally thyroxine-treated rats. Mech. Ageing Dev. 1983, 22, 113-120. [CrossRef]

46. Tatar, M.; Bartke, A.; Antebi, A. The Endocrine Regulation of Aging by Insulin-like Signals. Science 2003, $299,1346-1351$. [CrossRef]

47. Brown-Borg, H.M.; Borg, K.E.; Meliska, C.J.; Bartke, A. Dwarf mice and the ageing process. Nat. Cell Biol. 1996, 384, 33. [CrossRef]

48. Vergara, M.; Smith-Wheelock, M.; Harper, J.M.; Sigler, R.; Miller, R.A. Hormone-Treated Snell Dwarf Mice Regain Fertility But Remain Long Lived and Disease Resistant. J. Gerontol. Ser. A Boil. Sci. Med. Sci. 2004, 59, 1244-1250. [CrossRef] 
49. Buffenstein, R. The Naked Mole-Rat: A New Long-Living Model for Human Aging Research. J. Gerontol. Ser. A Boil. Sci. Med. Sci. 2005, 60, 1369-1377. [CrossRef] [PubMed]

50. Rozing, M.P.; Westendorp, R.G.J.; De Craen, A.J.M.; Frölich, M.; Heijmans, B.T.; Beekman, M.; Wijsman, C.; Mooijaart, S.P.; Blauw, G.-J.; Slagboom, P.E.; et al. Low Serum Free Triiodothyronine Levels Mark Familial Longevity: The Leiden Longevity Study. J. Gerontol. Ser. A Boil. Sci. Med. Sci. 2010, 65, 365-368. [CrossRef] [PubMed]

51. Rozing, M.P.; Houwing-Duistermaat, J.J.; Slagboom, P.E.; Beekman, M.; Frölich, M.; De Craen, A.J.M.; Westendorp, R.G.J.; Van Heemst, D. Familial Longevity Is Associated with Decreased Thyroid Function. J. Clin. Endocrinol. Metab. 2010, 95, 4979-4984. [CrossRef] [PubMed]

52. Formiga, F.; Ferrer, A. Thyrotropin Serum Values and 3-Year Mortality in Nonagenarians. J. Gerontol. Ser. A Boil. Sci. Med. Sci. 2010, 65, 1250-1251. [CrossRef] [PubMed]

53. Dubé, J.J.; Amati, F.; Toledo, F.G.S.; Stefanovic-Racic, M.; Rossi, A.; Coen, P.; Goodpaster, B.H. Effects of weight loss and exercise on insulin resistance, and intramyocellular triacylglycerol, diacylglycerol and ceramide. Diabetologia 2011, 54, 1147-1156. [CrossRef]

54. Most, J.; Gilmore, L.A.; Smith, S.R.; Han, H.; Ravussin, E.; Redman, L.M. Significant improvement in cardiometabolic health in healthy nonobese individuals during caloric restriction-induced weight loss and weight loss maintenance. Am. J. Physiol. Metab. 2018, 314, E396-E405. [CrossRef]

55. Fontana, L.; Weiss, E.P.; Villareal, D.T.; Klein, S.; Holloszy, J.O. Long-term effects of calorie or protein restriction on serum IGF-1 and IGFBP-3 concentration in humans. Aging Cell 2008, 7, 681-687. [CrossRef] [PubMed]

56. Redman, L.M.; Veldhuis, J.D.; Rood, J.; Smith, S.R.; Williamson, N.; Ravussin, E. The effect of caloric restriction interventions on growth hormone secretion in nonobese men and women. Aging Cell 2010, 9, 32-39. [CrossRef] [PubMed]

57. Dorling, J.L.; Ravussin, E.; Redman, L.M.; Bhapkar, M.; Huffman, K.M.; Racette, S.B.; Das, S.K.; Apolzan, J.W.; Kraus, W.E.; Höchsmann, C.; et al. Effect of 2 years of calorie restriction on liver biomarkers: Results from the CALERIE phase 2 randomized controlled trial. Eur. J. Nutr. 2020, 1-11. [CrossRef]

58. Fontana, L.; Meyer, T.E.; Klein, S.; Holloszy, J.O. Long-term calorie restriction is highly effective in reducing the risk for atherosclerosis in humans. Proc. Natl. Acad. Sci. USA 2004, 101, 6659-6663. [CrossRef] [PubMed]

59. De Jonge, L.; Moreira, E.A.; Martin, C.K.; Ravussin, E.; Team, P.C. Impact of 6-month Caloric Restriction on Autonomic Nervous System Activity in Healthy, Overweight, Individuals. Obesity 2010, 18, 414-416. [CrossRef]

60. Lefevre, M.; Redman, L.M.; Heilbronn, L.K.; Smith, J.V.; Martin, C.K.; Rood, J.C.; Greenway, F.L.; Williamson, D.A.; Smith, S.R.; Ravussin, E. Caloric restriction alone and with exercise improves CVD risk in healthy non-obese individuals. Atherosclerosis 2009, 203, 206-213. [CrossRef]

61. Ard, J.D.; Gower, B.; Hunter, G.; Ritchie, C.S.; Roth, D.L.; Goss, A.; Wingo, B.C.; Bodner, E.V.; Brown, C.J.; Bryan, D.; et al. Effects of Calorie Restriction in Obese Older Adults: The CROSSROADS Randomized Controlled Trial. J. Gerontol. Ser. A Boil. Sci. Med. Sci. 2016, 73, 73-80. [CrossRef]

62. Meydani, S.N.; Das, S.K.; Pieper, C.F.; Lewis, M.R.; Klein, S.; Dixit, V.D.; Gupta, A.K.; Villareal, D.T.; Bhapkar, M.; Huang, M.; et al. Long-term moderate calorie restriction inhibits inflammation without impairing cell-mediated immunity: A randomized controlled trial in non-obese humans. Aging 2016, 8, 1416-1431. [CrossRef] [PubMed]

63. Wang, A.; Huen, S.C.; Luan, H.H.; Yu, S.; Zhang, C.; Gallezot, J.-D.; Booth, C.J.; Medzhitov, R. Opposing Effects of Fasting Metabolism on Tissue Tolerance in Bacterial and Viral Inflammation. Cell 2016, 166, 1512-1525.e12. [CrossRef] [PubMed]

64. Cheng, C.-W.; Adams, G.B.; Perin, L.; Wei, M.; Zhou, X.; Lam, B.S.; Da Sacco, S.; Mirisola, M.; Quinn, D.I.; Dorff, T.B.; et al. Prolonged Fasting Reduces IGF-1/PKA to Promote Hematopoietic-Stem-Cell-Based Regeneration and Reverse Immunosuppression. Cell Stem Cell 2014, 14, 810-823. [CrossRef] [PubMed]

65. Puleston, D.J.; Zhang, H.; Powell, T.J.; Lipina, E.; Sims, S.; Panse, I.; Watson, A.S.; Cerundolo, V.; Townsend, A.R.; Rm, T.A.; et al. Autophagy is a critical regulator of memory CD8+ T cell formation. eLife 2014, 3, e03706. [CrossRef]

66. Di Biase, S.; Lee, C.; Brandhorst, S.; Manes, B.; Buono, R.; Cheng, C.-W.; Cacciottolo, M.; Martin-Montalvo, A.; De Cabo, R.; Wei, M.; et al. Fasting-Mimicking Diet Reduces HO-1 to Promote T Cell-Mediated Tumor Cytotoxicity. Cancer Cell 2016, 30, 136-146. [CrossRef]

67. Messaoudi, I.; Warner, J.; Fischer, M.; Park, B.; Hill, B.; Mattison, J.; Lane, M.A.; Roth, G.S.; Ingram, D.K.; Picker, L.J.; et al. Delay of T cell senescence by caloric restriction in aged long-lived nonhuman primates. Proc. Natl. Acad. Sci. USA 2006, 103, 19448-19453. [CrossRef]

68. Vodnala, S.K.; Eil, R.; Kishton, R.J.; Sukumar, M.; Yamamoto, T.N.; Ha, N.-H.; Lee, P.-H.; Shin, M.; Patel, S.J.; Yu, Z.; et al. T cell stemness and dysfunction in tumors are triggered by a common mechanism. Science 2019, 363, eaau0135. [CrossRef] [PubMed]

69. Impact of Dietary Intervention on Tumor Immunity: The DigesT Trial (DIgesT). Available online: https://clinicaltrials.gov/ct2 / show / NCT03454282 (accessed on 24 October 2020).

70. Michels, K.B. Caloric Restriction and Incidence of Breast Cancer. JAMA 2004, 291, 1226-1230. [CrossRef] [PubMed]

71. Rous, P. The Influence of Diet on Transplanted and Spontaneous Mouse Tumors. J. Exp. Med. 1914, 20, 433-451. [CrossRef] [PubMed]

72. Tannenbaum, A. Effects of varying caloric intake upon tumor incidence and tumor growth. Ann. N. Y. Acad. Sci. 1947, 49, 5-18. [CrossRef]

73. Vernieri, C.; Casola, S.; Foiani, M.; Pietrantonio, F.; De Braud, F.; Longo, V. Targeting Cancer Metabolism: Dietary and Pharmacologic Interventions. Cancer Discov. 2016, 6, 1315-1333. [CrossRef] [PubMed] 
74. Grasl-Kraupp, B.; Bursch, W.; Ruttkay-Nedecky, B.; Wägner, A.; Lauer, B.; Schulte-Hermann, R. Food restriction eliminates preneoplastic cells through apoptosis and antagonizes carcinogenesis in rat liver. Proc. Natl. Acad. Sci. USA 1994, 91, 9995-9999. [CrossRef]

75. Lok, E.; Scott, F.; Mongeau, R.; Nera, E.; Malcolm, S.; Clayson, D. Calorie restriction and cellular proliferation in various tissues of the female Swiss Webster mouse. Cancer Lett. 1990, 51, 67-73. [CrossRef]

76. Berrigan, D.; Perkins, S.N.; Haines, D.C.; Hursting, S.D. Adult-onset calorie restriction and fasting delay spontaneous tumorigenesis in p53-deficient mice. Carcinogenesis 2002, 23, 817-822. [CrossRef]

77. Hursting, S.D.; Lavigne, J.A.; Berrigan, D.; Perkins, S.N.; Barrett, J.C. Calorie Restriction, Aging, and Cancer Prevention: Mechanisms of Action and Applicability to Humans. Annu. Rev. Med. 2003, 54, 131-152. [CrossRef]

78. Hursting, S.D.; Smith, S.M.; Lashinger, L.M.; Harvey, A.E.; Perkins, S.N. Calories and carcinogenesis: Lessons learned from 30 years of calorie restriction research. Carcinogenesis 2009, 31, 83-89. [CrossRef] [PubMed]

79. Kiechl, S.; Pechlaner, R.; Willeit, P.; Notdurfter, M.; Paulweber, B.; Willeit, K.; Werner, P.; Ruckenstuhl, C.; Iglseder, B.; Weger, S.; et al. Higher spermidine intake is linked to lower mortality: A prospective population-based study. Am. J. Clin. Nutr. 2018, 108, 371-380. [CrossRef] [PubMed]

80. Pietrocola, F.; Castoldi, F.; Kepp, O.; Carmona-Gutierrez, D.; Madeo, F.; Kroemer, G. Spermidine reduces cancer-related mortality in humans. Autophagy 2019, 15, 362-365. [CrossRef] [PubMed]

81. Lévesque, S.; Pol, J.G.; Ferrere, G.; Galluzzi, L.; Zitvogel, L.; Kroemer, G. Trial watch: Dietary interventions for cancer therapy. OncoImmunology 2019, 8, e1591878. [CrossRef] [PubMed]

82. Safdie, F.M.; Dorff, T.; Quinn, D.; Fontana, L.; Wei, M.; Lee, C.; Cohen, P.; Longo, V.D. Fasting and cancer treatment in humans: A case series report. Aging 2009, 1, 988-1007. [CrossRef] [PubMed]

83. Dorff, T.B.; Groshen, S.; Garcia, A.; Shah, M.; Tsao-Wei, D.; Pham, H.; Cheng, C.-W.; Brandhorst, S.; Cohen, P.; Wei, M.; et al. Safety and feasibility of fasting in combination with platinum-based chemotherapy. BMC Cancer 2016, 16, 360. [CrossRef] [PubMed]

84. De Groot, S.; Vreeswijk, M.P.G.; Welters, M.J.P.; Gravesteijn, G.; Boei, J.J.W.A.; Jochems, A.; Houtsma, D.; Putter, H.; Van Der Hoeven, J.J.M.; Nortier, J.W.R.; et al. The effects of short-term fasting on tolerance to (neo) adjuvant chemotherapy in HER2-negative breast cancer patients: A randomized pilot study. BMC Cancer 2015, 15, 1-9. [CrossRef]

85. De Groot, S.; Pijl, H.; Van Der Hoeven, J.J.M.; Kroep, J.R. Effects of short-term fasting on cancer treatment. J. Exp. Clin. Cancer Res. 2019, 38, 1-14. [CrossRef] [PubMed]

86. Bauersfeld, S.P.; Kessler, C.S.; Wischnewsky, M.; Jaensch, A.; Steckhan, N.; Stange, R.; Kunz, B.; Brückner, B.; Sehouli, J.; Michalsen, A. The effects of short-term fasting on quality of life and tolerance to chemotherapy in patients with breast and ovarian cancer: A randomized cross-over pilot study. BMC Cancer 2018, 18, 476. [CrossRef] [PubMed]

87. De Groot, S.; Lugtenberg, R.T.; Cohen, D.; Welters, M.J.P.; Ehsan, I.; Vreeswijk, M.P.G.; Smit, V.T.H.B.M.; De Graaf, H.; Heijns, J.B.; Portielje, J.E.A.; et al. Fasting mimicking diet as an adjunct to neoadjuvant chemotherapy for breast cancer in the multicentre randomized phase 2 DIRECT trial. Nat. Commun. 2020, 11, 3083. [CrossRef] [PubMed]

88. DIetary REstriction as an Adjunct to Neoadjuvant ChemoTherapy for HER2 Negative Breast Cancer (DIRECT). Available online: https:/ / clinicaltrials.gov / ct2/show / NCT02126449 (accessed on 24 October 2020).

89. Vernieri, C.; Ligorio, F.; Zattarin, E.; Rivoltini, L.; De Braud, F. Fasting-mimicking diet plus chemotherapy in breast cancer treatment. Nat. Commun. 2020, 11, 1-4. [CrossRef] [PubMed]

90. Koppold-Liebscher, D.; Kessler, C.S.; Steckhan, N.; Bähr, V.; Kempter, C.; Wischnewsky, M.; Hübner, M.; Kunz, B.; Paul, M.; Zorn, S.; et al. Short-term fasting accompanying chemotherapy as a supportive therapy in gynecological cancer: Protocol for a multicenter randomized controlled clinical trial. Trials 2020, 21, 1-12. [CrossRef]

91. Fasting-Mimicking Diet in Patients Undergoing Active Cancer Treatment. Available online: https://clinicaltrials.gov/ct2/show/ NCT03595540 (accessed on 24 October 2020).

92. Fasting-Mimicking Diet With Chemo-Immunotherapy in Non-Small Cell Lung Cancer (NSCLC). Available online: https: / / clinicaltrials.gov/ct2/show / NCT03700437 (accessed on 24 October 2020).

93. Roth, L.W.; Polotsky, A.J. Can we live longer by eating less? A review of caloric restriction and longevity. Matur. 2012, 71, 315-319. [CrossRef] [PubMed]

94. Magkos, F.; Yannakoulia, M.; Chan, J.L.; Mantzoros, C.S. Management of the Metabolic Syndrome and Type 2 Diabetes Through Lifestyle Modification. Annu. Rev. Nutr. 2009, 29, 223-256. [CrossRef] [PubMed]

95. Madeo, F.; Pietrocola, F.; Eisenberg, T.; Kroemer, G. Caloric restriction mimetics: Towards a molecular definition. Nat. Rev. Drug Discov. 2014, 13, 727-740. [CrossRef] [PubMed]

96. Mariño, G.; Pietrocola, F.; Madeo, F.; Kroemer, G. Caloric restriction mimetics: Natural/physiological pharmacological autophagy inducers. Autophagy 2014, 10, 1879-1882. [CrossRef] [PubMed]

97. Raffaghello, L.; Lee, C.; Safdie, F.M.; Wei, M.; Madia, F.; Bianchi, G.; Longo, V.D. Starvation-dependent differential stress resistance protects normal but not cancer cells against high-dose chemotherapy. Proc. Natl. Acad. Sci. USA 2008, 105, 8215-8220. [CrossRef] [PubMed]

98. Tinkum, K.L.; Stemler, K.M.; White, L.S.; Loza, A.J.; Jeter-Jones, S.; Michalski, B.M.; Kuzmicki, C.; Pless, R.; Stappenbeck, T.S.; Piwnica-Worms, D.; et al. Fasting protects mice from lethal DNA damage by promoting small intestinal epithelial stem cell survival. Proc. Natl. Acad. Sci. USA 2015, 112, E7148-E7154. [CrossRef] 
99. Lee, C.; Raffaghello, L.; Brandhorst, S.; Safdie, F.M.; Bianchi, G.; Martin-Montalvo, A.; Pistoia, V.; Wei, M.; Hwang, S.; Merlino, A.; et al. Fasting Cycles Retard Growth of Tumors and Sensitize a Range of Cancer Cell Types to Chemotherapy. Sci. Transl. Med. 2012, 4, 124ra27. [CrossRef]

100. Perer, E.S.; Madan, A.K.; Shurin, A.; Zakris, E.; Romeguera, K.; Pang, Y.; Beech, D.J. Insulin-like Growth Factor I Receptor Antagonism Augments Response to Chemoradiation Therapy in Colon Cancer Cells. J. Surg. Res. 2000, 94, 1-5. [CrossRef]

101. Lee, C.; Safdie, F.M.; Raffaghello, L.; Wei, M.; Madia, F.; Parrella, E.; Hwang, D.; Cohen, P.; Bianchi, G.; Longo, V.D. Reduced Levels of IGF-I Mediate Differential Protection of Normal and Cancer Cells in Response to Fasting and Improve Chemotherapeutic Index. Cancer Res. 2010, 70, 1564-1572. [CrossRef]

102. Safdie, F.; Brandhorst, S.; Wei, M.; Wang, W.; Lee, C.; Hwang, S.; Conti, P.S.; Chen, T.C.; Longo, V.D. Fasting Enhances the Response of Glioma to Chemo- and Radiotherapy. PLoS ONE 2012, 7, e44603. [CrossRef] [PubMed]

103. Turner, B.C.; Haffty, B.G.; Narayanan, L.; Yuan, J.; Havre, P.A.; Gumbs, A.A.; Kaplan, L.; Burgaud, J.L.; Carter, D.; Baserga, R.; et al. Insulin-like growth factor-I receptor overexpression mediates cellular radioresistance and local breast cancer recurrence after lumpectomy and radiation. Cancer Res. 1997, 57, 3079-3083. [PubMed]

104. Lee, C.; Longo, V.D. Fasting vs dietary restriction in cellular protection and cancer treatment: From model organisms to patients. Oncogene 2011, 30, 3305-3316. [CrossRef]

105. Hanahan, D.; Weinberg, R.A. The Hallmarks of Cancer. Cell 2000, 100, 57-70. [CrossRef]

106. Hanahan, D.; Weinberg, R.A. Hallmarks of Cancer: The Next Generation. Cell 2011, 144, 646-674. [CrossRef]

107. Heiden, M.G.V.; Cantley, L.C.; Thompson, C.B. Understanding the Warburg effect: The metabolic requirements of cell proliferation. Science 2009, 324, 1029-1033. [CrossRef]

108. Kopeina, G.S.; Senichkin, V.V.; Zhivotovsky, B. Caloric restriction-A promising anti-cancer approach: From molecular mechanisms to clinical trials. Biochim. Biophys. Acta BBA Rev. Cancer 2017, 1867, 29-41. [CrossRef]

109. Bianchi, G.; Martella, R.; Ravera, S.; Marini, C.; Capitanio, S.; Orengo, A.; Emionite, L.; Lavarello, C.; Amaro, A.; Petretto, A.; et al. Fasting induces anti-Warburg effect that increases respiration but reduces ATP-synthesis to promote apoptosis in colon cancer models. Oncotarget 2015, 6, 11806-11819. [CrossRef]

110. Lee, A.S.; Hendershot, L.M. ER stress and cancer. Cancer Biol. Ther. 2006, 5, 721-722. [CrossRef]

111. Sui, X.; Chen, R.; Wang, Z.; Huang, Z.; Kong, N.; Zhang, M.; Han, W.; Lou, F.; Yang, J.; Zhang, Q.; et al. Autophagy and chemotherapy resistance: A promising therapeutic target for cancer treatment. Cell Death Dis. 2013, 4, e838. [CrossRef]

112. Michaud, M.; Martins, I.; Sukkurwala, A.Q.; Adjemian, S.; Ma, Y.; Pellegatti, P.; Shen, S.; Kepp, O.; Scoazec, M.; Mignot, G.; et al. Autophagy-Dependent Anticancer Immune Responses Induced by Chemotherapeutic Agents in Mice. Science 2011, 334, 1573-1577. [CrossRef] [PubMed]

113. Pietrocola, F.; Pol, J.; Vacchelli, E.; Rao, S.; Enot, D.P.; Baracco, E.E.; Levesque, S.; Castoldi, F.; Jacquelot, N.; Yamazaki, T.; et al. Caloric Restriction Mimetics Enhance Anticancer Immunosurveillance. Cancer Cell 2016, 30, 147-160. [CrossRef]

114. Pietrocola, F.; Pol, J.; Vacchelli, E.; Baracco, E.E.; Levesque, S.; Castoldi, F.; Maiuri, M.C.; Madeo, F.; Kroemer, G. Autophagy induction for the treatment of cancer. Autophagy 2016, 12, 1962-1964. [CrossRef] [PubMed]

115. Pietrocola, F.; Pol, J.; Kroemer, G. Fasting improves anticancer immunosurveillance via autophagy induction in malignant cells. Cell Cycle 2016, 15, 3327-3328. [CrossRef]

116. Clark, S.L. Cellular differentiation in the kidneys of newborn mice studied with the electron microscope. J. Cell Biol. 1957, 3, 349-362. [CrossRef]

117. De Duve, C. The Lysosome. Sci. Am. 1963, 208, 64-73. [CrossRef]

118. Tsukada, M.; Ohsumi, Y. Isolation and characterization of autophagy-defective mutants of Saccharomyces cerevisiae. FEBS Lett. 1993, 333, 169-174. [CrossRef]

119. Nakatogawa, H.; Ohsumi, Y. Molecular mechanisms of autophagy in yeast. Tanpakushitsu kakusan koso. Protein Nucleic Acid Enzyme 2008, 53 (Suppl. 16), 2099-2105.

120. Morishita, H.; Mizushima, N. Diverse Cellular Roles of Autophagy. Annu. Rev. Cell Dev. Biol. 2019, 35, 453-475. [CrossRef]

121. Gatica, D.; Lahiri, V.; Klionsky, D.J. Cargo recognition and degradation by selective autophagy. Nat. Cell Biol. 2018, $20,233-242$. [CrossRef] [PubMed]

122. Kaur, J.; Debnath, J. Autophagy at the crossroads of catabolism and anabolism. Nat. Rev. Mol. Cell Biol. 2015, 16, 461-472. [CrossRef] [PubMed]

123. Asano, T.; Komatsu, M.; Yamaguchi-Iwai, Y.; Ishikawa, F.; Mizushima, N.; Iwai, K. Distinct Mechanisms of Ferritin Delivery to Lysosomes in Iron-Depleted and Iron-Replete Cells. Mol. Cell. Biol. 2011, 31, 2040-2052. [CrossRef]

124. Kawamata, T.; Horie, T.; Matsunami, M.; Sasaki, M.; Ohsumi, Y. Zinc starvation induces autophagy in yeast. J. Biol. Chem. 2017, 292, 8520-8530. [CrossRef] [PubMed]

125. Rangarajan, N.; Kapoor, I.; Li, S.; Drossopoulos, P.; White, K.K.; Madden, V.J.; Dohlman, H.G. Potassium starvation induces autophagy in yeast. J. Biol. Chem. 2020, 295, 14189-14202. [CrossRef]

126. Bhutia, S.K. Autophagy in Tumor and Tumor Microenvironment; Springer: Singapore, 2020. Available online: https://books.google. $\mathrm{fr} /$ books?id=6pGTzQEACAAJ (accessed on 11 November 2020).

127. Piffoux, M.; Eriau, E.; Cassier, P.A. Autophagy as a therapeutic target in pancreatic cancer. Br. J. Cancer 2021, 124, 333-344. [CrossRef] [PubMed] 
128. Zitvogel, L.; Apetoh, L.; Ghiringhelli, F.; Kroemer, G. Immunological aspects of cancer chemotherapy. Nat. Rev. Immunol. 2008, 8 , 59-73. [CrossRef]

129. Narita, T.; Weinert, B.T.; Choudhary, C. Functions and mechanisms of non-histone protein acetylation. Nat. Rev. Mol. Cell Biol. 2019, 20, 156-174. [CrossRef] [PubMed]

130. Bánréti, Á.; Sass, M.; Graba, Y. The emerging role of acetylation in the regulation of autophagy. Autophagy 2013, 9, 819-829. [CrossRef] [PubMed]

131. Son, S.M.; Park, S.J.; Lee, H.; Siddiqi, F.; Lee, J.E.; Menzies, F.M.; Rubinsztein, D.C. Leucine Signals to mTORC1 via Its Metabolite Acetyl-Coenzyme A. Cell Metab. 2019, 29, 192-201.e7. [CrossRef]

132. Son, S.M.; Park, S.J.; Stamatakou, E.; Vicinanza, M.; Menzies, F.M.; Rubinsztein, D.C. Leucine regulates autophagy via acetylation of the mTORC1 component raptor. Nat. Commun. 2020, 11, 1-13. [CrossRef] [PubMed]

133. Guertin, D.A.; Sabatini, D.M. Defining the Role of mTOR in Cancer. Cancer Cell 2007, 12, 9-22. [CrossRef]

134. Jung, C.H.; Ro, S.-H.; Cao, J.; Otto, N.M.; Kim, D.-H. mTOR regulation of autophagy. FEBS Lett. 2010, 584, 1287-1295. [CrossRef] [PubMed]

135. Hay, N.; Sonenberg, N. Upstream and Downstream of mTOR. Genes Dev. 2004, 18, 1926-1945. [CrossRef]

136. Hardie, D.G. AMP-activated/SNF1 protein kinases: Conserved guardians of cellular energy. Nat. Rev. Mol. Cell Biol. 2007, 8, 774-785. [CrossRef]

137. Xiao, B.; Sanders, M.J.; Underwood, E.; Heath, R.J.; Mayer, F.V.; Carmena, D.; Jing, C.; Walker, P.A.; Eccleston, J.F.; Haire, L.F.; et al. Structure of mammalian AMPK and its regulation by ADP. Nat. Cell Biol. 2011, 472, 230-233. [CrossRef]

138. Lee, J.W.; Park, S.; Takahashi, Y.; Wang, H.-G. The Association of AMPK with ULK1 Regulates Autophagy. PLoS ONE 2010, 5 , e15394. [CrossRef]

139. Egan, D.F.; Shackelford, D.B.; Mihaylova, M.M.; Gelino, S.; Kohnz, R.A.; Mair, W.; Vasquez, D.S.; Joshi, A.; Gwinn, D.M.; Taylor, R.; et al. Phosphorylation of ULK1 (hATG1) by AMP-Activated Protein Kinase Connects Energy Sensing to Mitophagy. Science 2010, 331, 456-461. [CrossRef]

140. Kim, J.; Kundu, M.; Viollet, B.; Guan, K.-L. AMPK and mTOR regulate autophagy through direct phosphorylation of Ulk1. Nat. Cell Biol. 2011, 13, 132-141. [CrossRef]

141. Cantó, C.; Auwerx, J. Calorie Restriction: Is AMPK a Key Sensor and Effector? Physiology 2011, 26, 214-224. [CrossRef] [PubMed]

142. Tokunaga, C.; Yoshino, K.-I.; Yonezawa, K. mTOR integrates amino acid- and energy-sensing pathways. Biochem. Biophys. Res. Commun. 2004, 313, 443-446. [CrossRef]

143. Lin, S.-J.; Ford, E.; Haigis, M.; Liszt, G.; Guarente, L. Calorie restriction extends yeast life span by lowering the level of NADH. Genes Dev. 2004, 18, 12-16. [CrossRef]

144. Wang, Y. Molecular Links between Caloric Restriction and Sir2/SIRT1 Activation. Diabetes Metab. J. 2014, 38, 321-329. [CrossRef]

145. Madeo, F.; Carmona-Gutierrez, D.; Hofer, S.J.; Kroemer, G. Caloric Restriction Mimetics against Age-Associated Disease: Targets, Mechanisms, and Therapeutic Potential. Cell Metab. 2019, 29, 592-610. [CrossRef] [PubMed]

146. Pietrocola, F. Regulation of Autophagy by Acetyl Coenzime A: From the Mechanisms to a Revised Definition of CaloricRestriction Mimetics. Available online: https:// tel.archives-ouvertes.fr/tel-01580849 (accessed on 27 October 2020).

147. Phan, T.T.; Shivu, G.N.; Choudhury, A.; Abozguia, K.; Davies, C.; Naidoo, U.; Ahmed, I.; Yousef, Z.; Horowitz, J.; Frenneaux, M. Multi-centre experience on the use of perhexiline in chronic heart failure and refractory angina: Old drug, new hope. Eur. J. Hear. Fail. 2009, 11, 881-886. [CrossRef]

148. Hanai, J.-I.; Doro, N.; Seth, P.; Sukhatme, V.P. ATP citrate lyase knockdown impacts cancer stem cells in vitro. Cell Death Dis. 2013, 4, e696. [CrossRef]

149. Asghar, M.; Monjok, E.; Kouamou, G.; Ohia, S.E.; Bagchi, D.; Lokhandwala, M.F. Super CitriMax (HCA-SX) attenuates increases in oxidative stress, inflammation, insulin resistance, and body weight in developing obese Zucker rats. Mol. Cell. Biochem. 2007, 304, 93-99. [CrossRef] [PubMed]

150. Onakpoya, I.; Hung, S.K.; Perry, R.; Wider, B.; Ernst, E. The Use ofGarciniaExtract (Hydroxycitric Acid) as a Weight loss Supplement: A Systematic Review and Meta-Analysis of Randomised Clinical Trials. J. Obes. 2010, 2011, 1-9. [CrossRef] [PubMed]

151. Zhao, Y.; Huang, Z.-J.; Rahman, M.; Luo, Q.; Thorlacius, H. Radicicol, an Hsp90 inhibitor, inhibits intestinal inflammation and leakage in abdominal sepsis. J. Surg. Res. 2013, 182, 312-318. [CrossRef]

152. He, Y.; Li, Y.; Zhang, S.; Perry, B.; Zhao, T.; Wang, Y.; Sun, C. Radicicol, a heat shock protein 90 inhibitor, inhibits differentiation and adipogenesis in 3T3-L1 preadipocytes. Biochem. Biophys. Res. Commun. 2013, 436, 169-174. [CrossRef] [PubMed]

153. Sonoda, H.; Prachasilchai, W.; Kondo, H.; Yokota-Ikeda, N.; Oshikawa, S.; Ito, K.; Ikeda, M. The Protective Effect of Radicicol Against Renal Ischemia-Reperfusion Injury in Mice. J. Pharmacol. Sci. 2010, 112, 242-246. [CrossRef] [PubMed]

154. Conte, T.; Franco, D.; Baptista, I.; Bueno, C.; Selistre-De-Araújo, H.; Brum, P.; Moriscot, A.; Miyabara, E. Radicicol improves regeneration of skeletal muscle previously damaged by crotoxin in mice. Toxicon 2008, 52, 146-155. [CrossRef]

155. Griffin, T.M.; Valdez, T.V.; Mestril, R. Radicicol activates heat shock protein expression and cardioprotection in neonatal rat cardiomyocytes. Am. J. Physiol. Circ. Physiol. 2004, 287, H1081-H1088. [CrossRef] [PubMed]

156. Muñoz-Esparza, N.C.; Latorre-Moratalla, M.L.; Comas-Basté, O.; Toro-Funes, N.; Veciana-Nogués, M.T.; Vidal-Carou, M.C. Polyamines in Food. Front. Nutr. 2019, 6, 108. [CrossRef] [PubMed] 
157. Chen, X.; Zhang, X.; Lu, Y.; Shim, J.-Y.; Sang, S.; Sun, Z.; Chen, X. Chemoprevention of 7,12-dimethylbenz[a]anthracene (DMBA)induced Hamster Cheek Pouch Carcinogenesis by a 5-Lipoxygenase Inhibitor, Garcinol. Nutr. Cancer 2012, 64, 1211-1218. [CrossRef] [PubMed]

158. LaRocca, T.J.; Gioscia-Ryan, R.A.; Hearon, C.M.; Seals, D.R. The autophagy enhancer spermidine reverses arterial aging. Mech. Ageing Dev. 2013, 134, 314-320. [CrossRef] [PubMed]

159. Pietrocola, F.; Castoldi, F.; Maiuri, M.C.; Kroemer, G. Aspirin—another caloric-restriction mimetic. Autophagy 2018, 14, 1162-1163. [CrossRef]

160. Castoldi, F.; Pietrocola, F.; Maiuri, M.C.; Kroemer, G. Aspirin induces autophagy via inhibition of the acetyltransferase EP300. Oncotarget 2018, 9, 24574-24575. [CrossRef]

161. Pietrocola, F.; Castoldi, F.; Markaki, M.; Lachkar, S.; Chen, G.; Enot, D.P.; Durand, S.; Bossut, N.; Tong, M.; Malik, S.A.; et al. Aspirin Recapitulates Features of Caloric Restriction. Cell Rep. 2018, 22, 2395-2407. [CrossRef]

162. Pietrocola, F.; Mariño, G.; Lissa, D.; Vacchelli, E.; Malik, S.A.; Niso-Santano, M.; Zamzami, N.; Galluzzi, L.; Maiuri, M.C.; Kroemer, G. Pro-autophagic polyphenols reduce the acetylation of cytoplasmic proteins. Cell Cycle 2012, 11, 3851-3860. [CrossRef] [PubMed]

163. Lee, S.-Y.; Ku, H.-C.; Kuo, Y.-H.; Yang, K.-C.; Tu, P.-C.; Chiu, H.-L.; Su, M.-J. Caffeic acid ethanolamide prevents cardiac dysfunction through sirtuin dependent cardiac bioenergetics preservation. J. Biomed. Sci. 2015, 22, 1-11. [CrossRef] [PubMed]

164. Treviño-Saldaña, N.; García-Rivas, G. Regulation of Sirtuin-Mediated Protein Deacetylation by Cardioprotective Phytochemicals. Oxidative Med. Cell. Longev. 2017, 2017, 1-16. [CrossRef] [PubMed]

165. Murtaza, G.; Karim, S.; Akram, M.R.; Khan, S.A.; Azhar, S.; Mumtaz, A.; Bin Asad, M.H.H. Caffeic Acid Phenethyl Ester and Therapeutic Potentials. BioMed Res. Int. 2014, 2014, 1-9. [CrossRef] [PubMed]

166. Jara, J.A.; Castro-Castillo, V.; Saavedra-Olavarría, J.; Peredo, L.; Pavanni, M.; Jaña, F.; Letelier, M.E.; Parra, E.; Becker, M.I.; Morello, A.; et al. Antiproliferative and Uncoupling Effects of Delocalized, Lipophilic, Cationic Gallic Acid Derivatives on Cancer Cell Lines. Validation in Vivo in Singenic Mice. J. Med. Chem. 2014, 57, 2440-2454. [CrossRef] [PubMed]

167. Lu, Y.; Jiang, F.; Jiang, H.; Wu, K.; Zheng, X.; Cai, Y.; Katakowski, M.; Chopp, M.; To, S.-S.T. Gallic acid suppresses cell viability, proliferation, invasion and angiogenesis in human glioma cells. Eur. J. Pharmacol. 2010, 641, 102-107. [CrossRef] [PubMed]

168. Kim, M.-J.; Seong, A.-R.; Yoo, J.-Y.; Jin, C.-H.; Lee, Y.-H.; Kim, Y.J.; Lee, J.; Jun, W.J.; Yoon, H.-G. Gallic acid, a histone acetyltransferase inhibitor, suppresses $\beta$-amyloid neurotoxicity by inhibiting microglial-mediated neuroinflammation. Mol. Nutr. Food Res. 2011, 55, 1798-1808. [CrossRef] [PubMed]

169. Quideau, S.; Deffieux, D.; Douat-Casassus, C.; Pouységu, L. Plant Polyphenols: Chemical Properties, Biological Activities, and Synthesis. Angew. Chem. Int. Ed. 2011, 50, 586-621. [CrossRef] [PubMed]

170. Lu, S.-P.; Kato, M.; Lin, S.-J. Assimilation of Endogenous Nicotinamide Riboside Is Essential for Calorie Restriction-mediated Life Span Extension in Saccharomyces cerevisiae. J. Biol. Chem. 2009, 284, 17110-17119. [CrossRef]

171. Belenky, P.; Racette, F.G.; Bogan, K.L.; McClure, J.M.; Smith, J.S.; Brenner, C. Nicotinamide Riboside Promotes Sir2 Silencing and Extends Lifespan via Nrk and Urh1/Pnp1/Meu1 Pathways to NAD+. Cell 2007, 129, 473-484. [CrossRef]

172. Hatzivassiliou, G.; Zhao, F.; Bauer, D.E.; Andreadis, C.; Shaw, A.N.; Dhanak, D.; Hingorani, S.R.; Tuveson, D.A.; Thompson, C.B. ATP citrate lyase inhibition can suppress tumor cell growth. Cancer Cell 2005, 8, 311-321. [CrossRef]

173. Pearce, N.J.; Yates, J.W.; Berkhout, T.A.; Jackson, B.; Tew, D.; Boyd, H.; Camilleri, P.; Sweeney, P.; Gribble, A.D.; Shaw, A.; et al. The role of ATP citrate-lyase in the metabolic regulation of plasma lipids. Biochem. J. 1998, 334, 113-119. [CrossRef]

174. Minor, R.K.; Baur, J.A.; Gomes, A.P.; Ward, T.M.; Csiszar, A.; Mercken, E.M.; Abdelmohsen, K.; Shin, Y.-K.; Canto, C.; ScheibyeKnudsen, M.; et al. SRT1720 improves survival and healthspan of obese mice. Sci. Rep. 2011, 1, 70. [CrossRef]

175. Milne, J.C.; Lambert, P.D.; Schenk, S.; Carney, D.P.; Smith, J.J.; Gagne, D.J.; Jin, L.; Boss, O.; Perni, R.B.; Vu, C.B.; et al. Small molecule activators of SIRT1 as therapeutics for the treatment of type 2 diabetes. Nat. Cell Biol. 2007, 450, 712-716. [CrossRef] [PubMed]

176. Mitchell, S.J.; Martin-Montalvo, A.; Mercken, E.M.; Palacios, H.H.; Ward, T.M.; Abulwerdi, G.; Minor, R.K.; Vlasuk, G.P.; Ellis, J.L.; Sinclair, D.A.; et al. The SIRT1 Activator SRT1720 Extends Lifespan and Improves Health of Mice Fed a Standard Diet. Cell Rep. 2014, 6, 836-843. [CrossRef] [PubMed]

177. Hoffmann, E.; Wald, J.; Lavu, S.; Roberts, J.; Beaumont, C.; Haddad, J.; Elliott, P.; Westphal, C.; Jacobson, E. Pharmacokinetics and tolerability of SRT2104, a first-in-class small molecule activator of SIRT1, after single and repeated oral administration in man. Br. J. Clin. Pharmacol. 2012, 75, 186-196. [CrossRef] [PubMed]

178. Lasko, L.M.; Jakob, C.G.; Edalji, R.P.; Qiu, W.; Montgomery, D.; DiGiammarino, E.L.; Hansen, T.M.; Risi, R.M.; Frey, R.; Manaves, V.; et al. Discovery of a selective catalytic p300/CBP inhibitor that targets lineage-specific tumours. Nat. Cell Biol. 2017, 550, 128-132. [CrossRef]

179. Mariño, G.; Pietrocola, F.; Eisenberg, T.; Kong, Y.; Malik, S.A.; Andryushkova, A.; Schroeder, S.; Pendl, T.; Harger, A.; Niso-Santano, M.; et al. Regulation of Autophagy by Cytosolic Acetyl-Coenzyme A. Mol. Cell 2014, 53, 710-725. [CrossRef]

180. Liu, Y.; Wang, L.; Predina, J.D.; Han, R.; Beier, U.H.; Wang, L.-C.S.; Kapoor, V.; Bhatti, T.R.; Akimova, T.; Singhal, S.; et al. Inhibition of p300 impairs Foxp3+ T regulatory cell function and promotes antitumor immunity. Nat. Med. 2013, 19, 1173-1177. [CrossRef] [PubMed] 
181. Abozguia, K.; Elliott, P.; McKenna, W.; Phan, T.T.; Nallur-Shivu, G.; Ahmed, I.; Maher, A.R.; Kaur, K.; Taylor, J.; Henning, A.; et al. Metabolic Modulator Perhexiline Corrects Energy Deficiency and Improves Exercise Capacity in Symptomatic Hypertrophic Cardiomyopathy. Circulation 2010, 122, 1562-1569. [CrossRef] [PubMed]

182. Bricker, D.K.; Taylor, E.B.; Schell, J.C.; Orsak, T.; Boutron, A.; Chen, Y.-C.; Cox, J.E.; Cardon, C.M.; Van Vranken, J.G.; Dephoure, N.; et al. A Mitochondrial Pyruvate Carrier Required for Pyruvate Uptake in Yeast, Drosophila, and Humans. Science 2012, 337, 96-100. [CrossRef] [PubMed]

183. Zachar, Z.; Marecek, J.; Maturo, C.; Gupta, S.; Stuart, S.D.; Howell, K.; Schauble, A.; Lem, J.; Piramzadian, A.; Karnik, S.; et al. Non-redox-active lipoate derivates disrupt cancer cell mitochondrial metabolism and are potent anticancer agents in vivo. J. Mol. Med. 2011, 89, 1137-1148. [CrossRef] [PubMed]

184. Stuart, S.D.; Schauble, A.; Gupta, S.; Kennedy, A.D.; Keppler, B.R.; Bingham, P.M.; Zachar, Z. A strategically designed small molecule attacks alpha-ketoglutarate dehydrogenase in tumor cells through a redox process. Cancer Metab. 2014, 2, 4. [CrossRef] [PubMed]

185. Lee, K.C.; Shorr, R.; Rodriguez, R.; Maturo, C.; Boteju, L.W.; Sheldon, A. Formation and Anti-Tumor Activity of Uncommon In Vitro and In Vivo Metabolites of CPI-613, a Novel Anti-Tumor Compound That Selectively Alters Tumor Energy Metabolism. Drug Metab. Lett. 2011, 5, 163-182. [CrossRef]

186. Cappello, A.R.; Guido, C.; Santoro, A.; Santoro, M.; Capobianco, L.; Montanaro, D.; Madeo, M.; Andò, S.; Dolce, V.; Aquila, S. The Mitochondrial Citrate Carrier (CIC) Is Present and Regulates Insulin Secretion by Human Male Gamete. Endocrinology 2012, 153, 1743-1754. [CrossRef] [PubMed]

187. Guay, C.; Madiraju, S.M.; Aumais, A.; Joly, É.; Prentki, M. A Role for ATP-Citrate Lyase, Malic Enzyme, and Pyruvate/Citrate Cycling in Glucose-induced Insulin Secretion. J. Biol. Chem. 2007, 282, 35657-35665. [CrossRef] [PubMed]

188. Chen, G.; Xie, W.; Nah, J.; Sauvat, A.; Liu, P.; Pietrocola, F.; Sica, V.; Carmona-Gutierrez, D.; Zimmermann, A.; Pendl, T.; et al. 3,4-Dimethoxychalcone induces autophagy through activation of the transcription factors TFE 3 and TFEB. EMBO Mol. Med. 2019, 11, e10469. [CrossRef]

189. Carmona-Gutierrez, D.; Zimmermann, A.; Kainz, K.; Pietrocola, F.; Chen, G.; Maglioni, S.; Schiavi, A.; Nah, J.; Mertel, S.; Beuschel, C.B.; et al. The flavonoid $4,4^{\prime}$-dimethoxychalcone promotes autophagy-dependent longevity across species. Nat. Commun. 2019, 10, 1-17. [CrossRef] [PubMed]

190. Rajendran, P.; Ho, E.; E Williams, D.; Dashwood, R.H. Dietary phytochemicals, HDAC inhibition, and DNA damage/repair defects in cancer cells. Clin. Epigenetics 2011, 3, 4. [CrossRef]

191. Wu, Y.; He, L.; Zhang, L.; Chen, J.; Yi, Z.; Zhang, J.; Liu, M.; Pang, X. Anacardic Acid (6-Pentadecylsalicylic Acid) Inhibits Tumor Angiogenesis by Targeting Src/FAK/Rho GTPases Signaling Pathway. J. Pharmacol. Exp. Ther. 2011, 339, 403-411. [CrossRef]

192. Pietrocola, F.; Lachkar, S.; Enot, D.P.; Nisosantano, M.; Pedro, J.M.B.-S.; Sica, V.; Izzo, V.; Maiuri, M.C.; Madeo, F.; Marino, G.; et al. Spermidine induces autophagy by inhibiting the acetyltransferase EP300. Cell Death Differ. 2014, 22, 509-516. [CrossRef]

193. Chung, S.; Yao, H.; Caito, S.; Hwang, J.-W.; Arunachalam, G.; Rahman, I. Regulation of SIRT1 in cellular functions: Role of polyphenols. Arch. Biochem. Biophys. 2010, 501, 79-90. [CrossRef] [PubMed]

194. Mai, A.; Rotili, D.; Tarantino, D.; Ornaghi, P.; Tosi, F.; Vicidomini, C.; Sbardella, G.; Nebbioso, A.; Miceli, M.; Altucci, L.; et al. Small-Molecule Inhibitors of Histone Acetyltransferase Activity: Identification and Biological Properties. J. Med. Chem. 2006, 49, 6897-6907. [CrossRef]

195. Chimenti, F.; Bizzarri, B.; Maccioni, E.; Secci, D.; Bolasco, A.; Chimenti, P.; Fioravanti, R.; Granese, A.; Carradori, S.; Tosi, F.; et al. A Novel Histone Acetyltransferase Inhibitor Modulating Gcn5 Network: Cyclopentylidene-[4-(4'-chlorophenyl)thiazol-2yl)hydrazone. J. Med. Chem. 2009, 52, 530-536. [CrossRef]

196. Kubota, M.; Shimizu, M.; Sakai, H.; Yasuda, Y.; Terakura, D.; Baba, A.; Ohno, T.; Tsurumi, H.; Tanaka, T.; Moriwaki, H. Preventive Effects of Curcumin on the Development of Azoxymethane-Induced Colonic Preneoplastic Lesions in Male C57BL/KsJ$\mathrm{db} / \mathrm{dbObese}$ Mice. Nutr. Cancer 2012, 64, 72-79. [CrossRef] [PubMed]

197. Shakibaei, M.; Mobasheri, A.; Lueders, C.; Busch, F.; Shayan, P.; Goel, A. Curcumin Enhances the Effect of Chemotherapy against Colorectal Cancer Cells by Inhibition of NF-kB and Src Protein Kinase Signaling Pathways. PLoS ONE 2013, 8, e57218. [CrossRef]

198. Ryu, M.-J.; Cho, M.; Song, J.-Y.; Yun, Y.-S.; Choi, I.-W.; Kim, D.-E.; Park, B.-S.; Oh, S. Natural derivatives of curcumin attenuate the Wnt/ $\beta$-catenin pathway through down-regulation of the transcriptional coactivator p300. Biochem. Biophys. Res. Commun. 2008, 377, 1304-1308. [CrossRef] [PubMed]

199. Suckow, B.K.; Suckow, M.A. Lifespan Extension by the Antioxidant Curcumin in Drosophila Melanogaster. Int. J. Biomed. Sci. IJBS 2006, 2, 402-405.

200. Liao, V.H.-C.; Yu, C.-W.; Chu, Y.-J.; Li, W.-H.; Hsieh, Y.-C.; Wang, T.-T. Curcumin-mediated lifespan extension in Caenorhabditis elegans. Mech. Ageing Dev. 2011, 132, 480-487. [CrossRef] [PubMed]

201. Seo, K.-I.; Choi, M.-S.; Jung, U.J.; Kim, H.-J.; Yeo, J.; Jeon, S.-M.; Lee, M.-K. Effect of curcumin supplementation on blood glucose, plasma insulin, and glucose homeostasis related enzyme activities in diabeticdb/dbmice. Mol. Nutr. Food Res. 2008, 52, 995-1004. [CrossRef] [PubMed]

202. Sharma, R.A.; McLelland, H.R.; Hill, K.A.; Ireson, C.R.; Euden, S.A.; Manson, M.M.; Pirmohamed, M.; Marnett, L.J.; Gescher, A.J.; Steward, W.P. Pharmacodynamic and pharmacokinetic study of oral Curcuma extract in patients with colorectal cancer. Clin. Cancer Res. 2001, 7, 1894-1900. 
203. Rao, C.V.; Rivenson, A.; Simi, B.; Reddy, B.S. Chemoprevention of Colon Cancer by Dietary Curcumin. Ann. N. Y. Acad. Sci. 1995, 768, 201-204. [CrossRef] [PubMed]

204. Huang, M.T.; Lou, Y.R.; Ma, W.; Newmark, H.L.; Reuhl, K.R.; Conney, A.H. Inhibitory effects of dietary curcumin on forestomach, duodenal, and colon carcinogenesis in mice. Cancer Res. 1994, 54, 5841-5847.

205. Bimonte, S.; Barbieri, A.; Palma, G.; Luciano, A.; Rea, D.; Arra, C. Curcumin Inhibits Tumor Growth and Angiogenesis in an Orthotopic Mouse Model of Human Pancreatic Cancer. BioMed Res. Int. 2013, 2013, 1-8. [CrossRef]

206. Balasubramanyam, K.; Varier, R.A.; Altaf, M.; Swaminathan, V.; Siddappa, N.B.; Ranga, U.; Kundu, T.K. Curcumin, a Novel p300/CREB-binding Protein-specific Inhibitor of Acetyltransferase, Represses the Acetylation of Histone/Nonhistone Proteins and Histone Acetyltransferase-dependent Chromatin Transcription. J. Biol. Chem. 2004, 279, 51163-51171. [CrossRef] [PubMed]

207. Neckers, L.; Trepel, J.; Lee, S.; Chung, E.-J.; Lee, M.-J.; Jung, Y.-J.; Marcu, M.G. Curcumin is an Inhibitor of p300 Histone Acetylatransferase. Med. Chem. 2006, 2, 169-174. [CrossRef]

208. Morimoto, T.; Sunagawa, Y.; Kawamura, T.; Takaya, T.; Wada, H.; Nagasawa, A.; Komeda, M.; Fujita, M.; Shimatsu, A.; Kita, T.; et al. The dietary compound curcumin inhibits p300 histone acetyltransferase activity and prevents heart failure in rats. J. Clin. Investig. 2008, 118, 868-878. [CrossRef]

209. Sunagawa, Y.; Morimoto, T.; Wada, H.; Takaya, T.; Katanasaka, Y.; Kawamura, T.; Yanagi, S.; Marui, A.; Sakata, R.; Shimatsu, A.; et al. A natural p300-specific histone acetyltransferase inhibitor, curcumin, in addition to angiotensin-converting enzyme inhibitor, exerts beneficial effects on left ventricular systolic function after myocardial infarction in rats. Circ. J. 2011, 75, 2151-2159. [CrossRef] [PubMed]

210. Kang, S.-K.; Cha, S.-H.; Jeon, H.-G. Curcumin-induced Histone Hypoacetylation Enhances Caspase-3-dependent Glioma Cell Death and Neurogenesis of Neural Progenitor Cells. Stem Cells Dev. 2006, 15, 165-174. [CrossRef]

211. Chen, Y.-K.; Cheung, C.; Reuhl, K.R.; Liu, A.B.; Lee, M.-J.; Lu, Y.-P.; Yang, C.S. Effects of Green Tea Polyphenol (-)Epigallocatechin-3-gallate on Newly Developed High-Fat/Western-Style Diet-Induced Obesity and Metabolic Syndrome in Mice. J. Agric. Food Chem. 2011, 59, 11862-11871. [CrossRef] [PubMed]

212. Jang, H.-J.; Ridgeway, S.D.; Kim, J.-A. Effects of the green tea polyphenol epigallocatechin-3-gallate on high-fat diet-induced insulin resistance and endothelial dysfunction. Am. J. Physiol. Metab. 2013, 305, E1444-E1451. [CrossRef] [PubMed]

213. Niu, Y.; Na, L.; Feng, R.; Gong, L.; Zhao, Y.; Li, Q.; Li, Y.; Sun, C. The phytochemical, EGCG, extends lifespan by reducing liver and kidney function damage and improving age-associated inflammation and oxidative stress in healthy rats. Aging Cell 2013, 12, 1041-1049. [CrossRef] [PubMed]

214. Li, F.; Shanmugam, M.K.; Chen, L.; Chatterjee, S.; Basha, J.; Kumar, A.P.; Kundu, T.K.; Sethi, G. Garcinol, a Polyisoprenylated Benzophenone Modulates Multiple Proinflammatory Signaling Cascades Leading to the Suppression of Growth and Survival of Head and Neck Carcinoma. Cancer Prev. Res. 2013, 6, 843-854. [CrossRef] [PubMed]

215. Arif, M.; Pradhan, S.K.; Thanuja, G.R.; Vedamurthy, B.M.; Agrawal, S.; Dasgupta, D.; Kundu, T.K. Mechanism of p300 Specific Histone Acetyltransferase Inhibition by Small Molecules. J. Med. Chem. 2009, 52, 267-277. [CrossRef]

216. Yum, S.; Doh, H.-J.; Hong, S.; Jeong, S.; Kim, D.-D.; Park, M.; Jung, Y. Piceatannol, a hydroxystilbene natural product, stabilizes HIF-1 $\alpha$ protein by inhibiting HIF prolyl hydroxylase. Eur. J. Pharmacol. 2013, 699, 124-131. [CrossRef]

217. Kinoshita, Y.; Kawakami, S.; Yanae, K.; Sano, S.; Uchida, H.; Inagaki, H.; Ito, T. Effect of long-term piceatannol treatment on eNOS levels in cultured endothelial cells. Biochem. Biophys. Res. Commun. 2013, 430, 1164-1168. [CrossRef]

218. Kwon, J.Y.; Seo, S.G.; Heo, Y.-S.; Yue, S.; Cheng, J.-X.; Lee, K.W.; Kim, K.-H. Piceatannol, Natural Polyphenolic Stilbene, Inhibits Adipogenesis via Modulation of Mitotic Clonal Expansion and Insulin Receptor-dependent Insulin Signaling in Early Phase of Differentiation. J. Biol. Chem. 2012, 287, 11566-11578. [CrossRef]

219. Minakawa, M.; Miura, Y.; Yagasaki, K. Piceatannol, a resveratrol derivative, promotes glucose uptake through glucose transporter 4 translocation to plasma membrane in L6 myocytes and suppresses blood glucose levels in type 2 diabetic model db/db mice. Biochem. Biophys. Res. Commun. 2012, 422, 469-475. [CrossRef] [PubMed]

220. Angst, E.; Park, J.L.; Moro, A.; Lu, Q.-Y.; Lu, X.; Li, G.; King, J.; Chen, M.; Reber, H.A.; Go, V.L.W.; et al. The Flavonoid Quercetin Inhibits Pancreatic Cancer Growth In Vitro and In Vivo. Pancreas 2013, 42, 223-229. [CrossRef] [PubMed]

221. Pratheeshkumar, P.; Budhraja, A.; Son, Y.-O.; Wang, X.; Zhang, Z.; Ding, S.; Wang, L.; Hitron, A.; Lee, J.-C.; Xu, M.; et al. Quercetin Inhibits Angiogenesis Mediated Human Prostate Tumor Growth by Targeting VEGFR- 2 Regulated AKT/mTOR/P70S6K Signaling Pathways. PLoS ONE 2012, 7, e47516. [CrossRef] [PubMed]

222. Dong, J.; Zhang, X.; Zhang, L.; Bian, H.-X.; Xu, N.; Bao, B.; Liu, J. Quercetin reduces obesity-associated ATM infiltration and inflammation in mice: A mechanism including AMPK $\alpha 1 /$ SIRT1. J. Lipid Res. 2014, 55, 363-374. [CrossRef]

223. Timmers, S.; Konings, E.; Bilet, L.; Houtkooper, R.H.; van de Weijer, T.; Goossens, G.H.; Hoeks, J.; van der Krieken, S.; Ryu, D.; Kersten, S.; et al. Calorie Restriction-like Effects of 30 Days of Resveratrol Supplementation on Energy Metabolism and Metabolic Profile in Obese Humans. Cell Metab. 2011, 14, 612-622. [CrossRef] [PubMed]

224. Lissa, D.; Senovilla, L.; Rello-Varona, S.; Vitale, I.; Michaud, M.; Pietrocola, F.; Boilève, A.; Obrist, F.; Bordenave, C.; Garcia, P.; et al. Resveratrol and aspirin eliminate tetraploid cells for anticancer chemoprevention. Proc. Natl. Acad. Sci. USA 2014, 111, 3020-3025. [CrossRef] [PubMed]

225. Pearson, K.J.; Baur, J.A.; Lewis, K.N.; Peshkin, L.; Price, N.L.; Labinskyy, N.; Swindell, W.R.; Kamara, D.; Minor, R.K.; Perez, E.; et al. Resveratrol Delays Age-Related Deterioration and Mimics Transcriptional Aspects of Dietary Restriction without Extending Life Span. Cell Metab. 2008, 8, 157-168. [CrossRef] [PubMed] 
226. Liu, K.; Zhou, R.; Wang, B.; Mi, M.-T. Effect of resveratrol on glucose control and insulin sensitivity: A meta-analysis of 11 randomized controlled trials. Am. J. Clin. Nutr. 2014, 99, 1510-1519. [CrossRef]

227. Fiori, J.L.; Shin, Y.-K.; Kim, W.; Krzysik-Walker, S.M.; González-Mariscal, I.; Carlson, O.D.; Sanghvi, M.; Moaddel, R.; Farhang, K.; Gadkaree, S.K.; et al. Resveratrol Prevents -Cell Dedifferentiation in Nonhuman Primates Given a High-Fat/High-Sugar Diet. Diabetes 2013, 62, 3500-3513. [CrossRef] [PubMed]

228. Hubbard, B.P.; Gomes, A.P.; Dai, H.; Li, J.; Case, A.W.; Considine, T.; Riera, T.V.; Lee, J.E.; McPhail, S.D.; Lamming, D.W.; et al. Evidence for a Common Mechanism of SIRT1 Regulation by Allosteric Activators. Science 2013, 339, 1216-1219. [CrossRef]

229. Park, S.-J.; Ahmad, F.; Philp, A.; Baar, K.; Williams, T.; Luo, H.; Ke, H.; Rehmann, H.; Taussig, R.; Brown, A.L.; et al. Resveratrol Ameliorates Aging-Related Metabolic Phenotypes by Inhibiting cAMP Phosphodiesterases. Cell 2012, 148, 421-433. [CrossRef] [PubMed]

230. Eisenberg, T.; Knauer, H.; Schauer, A.; Büttner, S.; Ruckenstuhl, C.; Carmona-Gutierrez, D.; Ring, J.; Schroeder, S.; Magnes, C.; Antonacci, L.; et al. Induction of autophagy by spermidine promotes longevity. Nat. Cell Biol. 2009, 11, 1305-1314. [CrossRef]

231. Bauer, M.A.; Carmona-Gutierrez, D.; Ruckenstuhl, C.; Reisenbichler, A.; Megalou, E.V.; Eisenberg, T.; Magnes, C.; Jungwirth, H.; Sinner, F.M.; Pieber, T.R.; et al. Spermidine promotes mating and fertilization efficiency in model organisms. Cell Cycle 2013, 12, 346-352. [CrossRef]

232. Soda, K.; Kano, Y.; Chiba, F.; Koizumi, K.; Miyaki, Y. Increased Polyamine Intake Inhibits Age-Associated Alteration in Global DNA Methylation and 1,2-Dimethylhydrazine-Induced Tumorigenesis. PLoS ONE 2013, 8, e64357. [CrossRef]

233. Matsumoto, M.; Kurihara, S.; Kibe, R.; Ashida, H.; Benno, Y. Longevity in Mice Is Promoted by Probiotic-Induced Suppression of Colonic Senescence Dependent on Upregulation of Gut Bacterial Polyamine Production. PLoS ONE 2011, 6, e23652. [CrossRef]

234. Paul, S.; Kang, S.C. Natural polyamine inhibits mouse skin inflammation and macrophage activation. Inflamm. Res. 2013, 62, 681-688. [CrossRef]

235. Pietrocola, F.; Castoldi, F.; Madeo, F.; Kroemer, G. Triethylenetetramine (trientine): A caloric restriction mimetic with a new mode of action. Autophagy 2020, 16, 1534-1536. [CrossRef]

236. Lévesque, S.; Le Naour, J.; Pietrocola, F.; Paillet, J.; Kremer, M.; Castoldi, F.; Baracco, E.E.; Wang, Y.; Vacchelli, E.; Stoll, G.; et al. A synergistic triad of chemotherapy, immune checkpoint inhibitors, and caloric restriction mimetics eradicates tumors in mice. OncoImmunology 2019, 8, e1657375. [CrossRef] [PubMed]

237. Verdura, S.; Cuyàs, E.; Cortada, E.; Brunet, J.; Lopez-Bonet, E.; Martin-Castillo, B.; Bosch-Barrera, J.; Encinar, J.A.; Menendez, J.A. Resveratrol targets PD-L1 glycosylation and dimerization to enhance antitumor T-cell immunity. Aging 2020, 12, 8-34. [CrossRef] [PubMed]

238. Farazi, M.; Nguyen, J.; Goldufsky, J.; Linnane, S.; Lukaesko, L.; Weinberg, A.D.; Ruby, C.E. Caloric restriction maintains OX40 agonist-mediated tumor immunity and CD4 T cell priming during aging. Cancer Immunol. Immunother. 2014, 63, 615-626. [CrossRef]

239. Jung, L.K.; Palladino, M.A.; Calvano, S.; Mark, D.A.; Good, R.A.; Fernandes, G. Effect of calorie restriction on the production and responsiveness to interleukin 2 in (NZB $\times$ NZW)F1 mice. Clin. Immunol. Immunopathol. 1982, 25, 295-301. [CrossRef]

240. Caffa, I.; D’Agostino, V.; Damonte, P.; Soncini, D.; Cea, M.; Monacelli, F.; Odetti, P.; Ballestrero, A.; Provenzani, A.; Longo, V.D.; et al. Fasting potentiates the anticancer activity of tyrosine kinase inhibitors by strengthening MAPK signaling inhibition. Oncotarget 2015, 6, 11820-11832. [CrossRef]

241. Nencioni, A.; Caffa, I.; Raffaghello, L.; Montecucco, F.; Cea, M.; Monacelli, F.; Grossi, F.; Patrone, F.; Odetti, P.; Ballestrero, A.; et al. Potentiation of crizotinib activity by fasting cycles in an ALK+ lung cancer model. J. Clin. Oncol. 2014, 32, e13511. [CrossRef]

242. Scheubeck, G.; Berchtold, S.; Smirnow, I.; Schenk, A.; Beil, J.; Lauer, U.M. Starvation-Induced Differential Virotherapy Using an Oncolytic Measles Vaccine Virus. Viruses 2019, 11, 614. [CrossRef] [PubMed]

243. Esaki, S.; Rabkin, S.D.; Martuza, R.L.; Wakimoto, H. Transient fasting enhances replication of oncolytic herpes simplex virus in glioblastoma. Am. J. Cancer Res. 2016, 6, 300-311.

244. Orsini, F.; Pavelic, Z.; Mihich, E. Increased primary cell-mediated immunity in culture subsequent to adriamycin or daunorubicin treatment of spleen donor mice. Cancer Res. 1977, 37, 1719-1726.

245. Arinaga, S.; Akiyoshi, T.; Tsuji, H. Augmentation of the generation of cell-mediated cytotoxicity after a single dose of adriamycin in cancer patients. Cancer Res. 1986, 46, 4213-4216. [PubMed]

246. Kerr, J.F.R.; Wyllie, A.H.; Currie, A.R. Apoptosis: A Basic Biological Phenomenon with Wideranging Implications in Tissue Kinetics. Br. J. Cancer 1972, 26, 239-257. [CrossRef] [PubMed]

247. Green, D.R.; Ferguson, T.; Zitvogel, L.; Kroemer, G. Immunogenic and tolerogenic cell death. Nat. Rev. Immunol. 2009, 9, 353-363. [CrossRef]

248. Zitvogel, L.; Kepp, O.; Kroemer, G. Immune parameters affecting the efficacy of chemotherapeutic regimens. Nat. Rev. Clin. Oncol. 2011, 8, 151-160. [CrossRef] [PubMed]

249. Kroemer, G.; Galluzzi, L.; Kepp, O.; Zitvogel, L. Immunogenic Cell Death in Cancer Therapy. Annu. Rev. Immunol. 2013, 31, 51-72. [CrossRef]

250. Tufi, R.; Panaretakis, T.; Bianchi, K.; Criollo, A.; Fazi, B.; Di Sano, F.; Tesniere, A.; Kepp, O.; Paterlini-Brechot, P.; Zitvogel, L.; et al. Reduction of endoplasmic reticulum Ca2+ levels favors plasma membrane surface exposure of calreticulin. Cell Death Differ. 2007, 15, 274-282. [CrossRef] 
251. Martins, I.; Kepp, O.; Schlemmer, F.; Adjemian, S.; Tailler, M.; Shen, S.; Michaud, M.; Menger, L.; Gdoura, A.; Tajeddine, N.; et al. Restoration of the immunogenicity of cisplatin-induced cancer cell death by endoplasmic reticulum stress. Oncogene 2010, 30, 1147-1158. [CrossRef]

252. Panaretakis, T.; Kepp, O.; Brockmeier, U.; Tesniere, A.; Bjorklund, A.-C.; Chapman, D.C.; Durchschlag, M.; Joza, N.; Pierron, G.; Van Endert, P.; et al. Mechanisms of pre-apoptotic calreticulin exposure in immunogenic cell death. EMBO J. 2009, 28, 578-590. [CrossRef]

253. Garg, A.D.; Krysko, D.V.; Verfaillie, T.; Kaczmarek, A.; Ferreira, G.B.; Marysael, T.; Rubio, N.; Firczuk, M.; Mathieu, C.; Roebroek, A.J.M.; et al. A novel pathway combining calreticulin exposure and ATP secretion in immunogenic cancer cell death. EMBO J. 2012, 31, 1062-1079. [CrossRef]

254. Andersson, U.; Tracey, K.J. HMGB1 Is a Therapeutic Target for Sterile Inflammation and Infection. Annu. Rev. Immunol. 2011, 29, 139-162. [CrossRef]

255. Elliott, M.R.; Chekeni, F.B.; Trampont, P.C.; Lazarowski, E.R.; Kadl, A.; Walk, S.F.; Park, D.; Woodson, R.I.; Ostankovich, M.; Sharma, P.; et al. Nucleotides released by apoptotic cells act as a find-me signal to promote phagocytic clearance. Nat. Cell Biol. 2009, 461, 282-286. [CrossRef]

256. Vacchelli, E.; Ma, Y.; Baracco, E.E.; Sistigu, A.; Enot, D.P.; Pietrocola, F.; Yang, H.; Adjemian, S.; Chaba, K.; Semeraro, M.; et al. Chemotherapy-induced antitumor immunity requires formyl peptide receptor 1. Science 2015, 350, 972-978. [CrossRef] [PubMed]

257. Gardai, S.J.; McPhillips, K.A.; Frasch, S.C.; Janssen, W.J.; Starefeldt, A.; Murphy-Ullrich, J.E.; Bratton, D.L.; Oldenborg, P.-A.; Michalak, M.; Henson, P.M. Cell-Surface Calreticulin Initiates Clearance of Viable or Apoptotic Cells through trans-Activation of LRP on the Phagocyte. Cell 2005, 123, 321-334. [CrossRef]

258. Apetoh, L.; Ghiringhelli, F.; Tesniere, A.; Obeid, M.; Ortiz, C.; Criollo, A.; Mignot, G.; Maiuri, M.C.; Ullrich, E.; Saulnier, P.; et al. Toll-like receptor 4-dependent contribution of the immune system to anticancer chemotherapy and radiotherapy. Nat. Med. 2007, 13, 1050-1059. [CrossRef] [PubMed]

259. Ghiringhelli, F.; Apetoh, L.; Tesniere, A.; Aymeric, L.; Ma, Y.; Ortiz, C.; Vermaelen, K.; Panaretakis, T.; Mignot, G.; Ullrich, E.; et al. Activation of the NLRP3 inflammasome in dendritic cells induces IL-1 $\beta$-dependent adaptive immunity against tumors. Nat. Med. 2009, 15, 1170-1178. [CrossRef] [PubMed]

260. Vacchelli, E.; Sistigu, A.; Yamazaki, T.; Vitale, I.; Zitvogel, L.; Kroemer, G. Autocrine signaling of type 1 interferons in successful anticancer chemotherapy. OncoImmunology 2015, 4.

261. Kepp, O.; Zitvogel, L.; Kroemer, G. Clinical evidence that immunogenic cell death sensitizes to PD-1/PD-L1 blockade. OncoImmunology 2019, 8, e1637188. [CrossRef]

262. Zhou, J.; Wang, G.; Chen, Y.; Wang, H.; Hua, Y.; Cai, Z. Immunogenic cell death in cancer therapy: Present and emerging inducers. J. Cell. Mol. Med. 2019, 23, 4854-4865. [CrossRef]

263. Galluzzi, L.; Kepp, O.; Kroemer, G. Immunogenic cell death in radiation therapy. OncoImmunology 2013, 2, e26536. [CrossRef] [PubMed]

264. Ko, A.; Kanehisa, A.; Martins, I.; Senovilla, L.; Chargari, C.; Dugue, D.; Marino, G.; Kepp, O.; Michaud, M.; Perfettini, J.-L.; et al. Autophagy inhibition radiosensitizes in vitro, yet reduces radioresponses in vivo due to deficient immunogenic signalling. Cell Death Differ. 2014, 21, 92-99. [CrossRef]

265. Casares, N.; Pequignot, M.O.; Tesniere, A.; Ghiringhelli, F.; Roux, S.; Chaput, N.; Schmitt, E.; Hamai, A.; Hervas-Stubbs, S.; Obeid, M.; et al. Caspase-dependent immunogenicity of doxorubicin-induced tumor cell death. J. Exp. Med. 2005, 202, 1691-1701. [CrossRef] [PubMed]

266. Du, B.; Waxman, D.J. Medium dose intermittent cyclophosphamide induces immunogenic cell death and cancer cell autonomous type I interferon production in glioma models. Cancer Lett. 2020, 470, 170-180. [CrossRef] [PubMed]

267. Nakahara, T.; Uchi, H.; Lesokhin, A.M.; Avogadri, F.; Rizzuto, G.A.; Hirschhorn-Cymerman, D.; Panageas, K.S.; Merghoub, T.; Wolchok, J.D.; Houghton, A.N. Cyclophosphamide enhances immunity by modulating the balance of dendritic cell subsets in lymphoid organs. Blood 2010, 115, 4384-4392. [CrossRef]

268. Sun, F.; Cui, L.; Li, T.; Chen, S.; Song, J.; Li, D. Oxaliplatin induces immunogenic cells death and enhances therapeutic efficacy of checkpoint inhibitor in a model of murine lung carcinoma. J. Recept. Signal Transduct. 2019, 39, 208-214. [CrossRef] [PubMed]

269. Tesniere, A.; Schlemmer, F.; Boige, V.; Kepp, O.; Martins, I.; Ghiringhelli, F.; Aymeric, L.; Michaud, M.; Apetoh, L.; Barault, L.; et al. Immunogenic death of colon cancer cells treated with oxaliplatin. Oncogene 2009, 29, 482-491. [CrossRef]

270. Liu, P.; Zhao, L.; Kepp, O.; Kroemer, G. Crizotinib-A tyrosine kinase inhibitor that stimulates immunogenic cell death. OncoImmunology 2019, 8, 1596652-1596653. [CrossRef]

271. Novosiadly, R.; Schaer, D.; Amaladas, N.; Rasmussen, E.; Lu, Z.H.; Sonyi, A.; Carpenito, C.; Li, Y.; Luo, S.; Capen, A.; et al. Abstract 4549: Pemetrexed enhances anti-tumor efficacy of PD1 pathway blockade by promoting intra tumor immune response via immunogenic tumor cell death and T cell intrinsic mechanisms. Clin. Res. Exclud. Clin. Trials 2018, 78, 4549. [CrossRef]

272. Menger, L.; Vacchelli, E.; Adjemian, S.; Martins, I.; Ma, Y.; Shen, S.; Yamazaki, T.; Sukkurwala, A.Q.; Michaud, M.; Mignot, G.; et al. Cardiac Glycosides Exert Anticancer Effects by Inducing Immunogenic Cell Death. Sci. Transl. Med. 2012, 4, 143ra99. [CrossRef]

273. Fucikova, J.; Moserova, I.; Truxova, I.; Hermanova, I.; Vancurova, I.; Partlova, S.; Fialova, A.; Sojka, L.; Cartron, P.-F.; Houska, M.; et al. High hydrostatic pressure induces immunogenic cell death in human tumor cells. Int. J. Cancer 2014, 135, 1165-1177. [CrossRef] [PubMed] 
274. Galluzzi, L.; Kepp, O.; Kroemer, G. Enlightening the impact of immunogenic cell death in photodynamic cancer therapy. EMBO J. 2012, 31, 1055-1057. [CrossRef]

275. Workenhe, S.T.; Mossman, K.L. Oncolytic Virotherapy and Immunogenic Cancer Cell Death: Sharpening the Sword for Improved Cancer Treatment Strategies. Mol. Ther. 2014, 22, 251-256. [CrossRef] [PubMed]

276. Miyamoto, S.; Inoue, H.; Nakamura, T.; Yamada, M.; Sakamoto, C.; Urata, Y.; Okazaki, T.; Marumoto, T.; Takahashi, A.; Takayama, K.; et al. Coxsackievirus B3 Is an Oncolytic Virus with Immunostimulatory Properties That Is Active against Lung Adenocarcinoma. Cancer Res. 2012, 72, 2609-2621. [CrossRef] [PubMed]

277. Donnelly, O.G.; Errington-Mais, F.; Steele, L.; Hadac, E.M.; Jennings, V.; Scott, K.P.; Peach, H.; Phillips, R.M.; Bond, J.; Pandha, H.; et al. Measles virus causes immunogenic cell death in human melanoma. Gene Ther. 2013, 20, 7-15. [CrossRef]

278. Diaconu, I.; Cerullo, V.; Hirvinen, M.L.; Escutenaire, S.; Ugolini, M.; Pesonen, S.K.; Bramante, S.; Parviainen, S.; Kanerva, A.; Loskog, A.S.; et al. Immune Response Is an Important Aspect of the Antitumor Effect Produced by a CD40L-Encoding Oncolytic Adenovirus. Cancer Res. 2012, 72, 2327-2338. [CrossRef] [PubMed]

279. Boozari, B.; Mundt, B.; Woller, N.; Strüver, N.; Gürlevik, E.; Schache, P.; Kloos, A.; Knocke, S.; Manns, M.P.; Wirth, T.C.; et al Antitumoural immunity by virus-mediated immunogenic apoptosis inhibits metastatic growth of hepatocellular carcinoma. Gut 2010, 59, 1416-1426. [CrossRef] [PubMed]

280. Workenhe, S.T.; Simmons, G.; Pol, J.G.; Lichty, B.D.; Halford, W.P.; Mossman, K.L. Immunogenic HSV-mediated Oncolysis Shapes the Antitumor Immune Response and Contributes to Therapeutic Efficacy. Mol. Ther. 2014, 22, 123-131. [CrossRef]

281. Workenhe, S.T.; Pol, J.G.; Lichty, B.D.; Cummings, D.T.; Mossman, K.L. Combining Oncolytic HSV-1 with Immunogenic Cell Death-Inducing Drug Mitoxantrone Breaks Cancer Immune Tolerance and Improves Therapeutic Efficacy. Cancer Immunol. Res. 2013, 1, 309-319. [CrossRef]

282. Zhou, H.; Forveille, S.; Sauvat, A.; Yamazaki, T.; Senovilla, L.; Ma, Y.; Liu, P.; Yang, H.; Bezu, L.; Müller, K.; et al. The oncolytic peptide LTX-315 triggers immunogenic cell death. Cell Death Dis. 2016, 7, e2134. [CrossRef]

283. Jebsen, N.L.; Apelseth, T.O.; Haugland, H.K.; Rekdal, Ø.; Patel, H.; Gjertsen, B.T.; Jøssang, D.E. Enhanced T-lymphocyte infiltration in a desmoid tumor of the thoracic wall in a young woman treated with intratumoral injections of the oncolytic peptide LTX-315: A case report. J. Med Case Rep. 2019, 13, 177. [CrossRef]

284. Spicer, J.F.; Baurain, J.-F.; Awada, A.; Kristeleit, R.S.; Jossang, D.E.; Marabelle, A.; Loirat, D.; Wold, H.; Nicolaisen, B.; Rekdal, O.; et al. LTX-315, an oncolytic peptide, to convert immunogenically 'cold' tumors to 'hot' in patients with advanced or metastatic tumours: Results from an ongoing phase I study. J. Clin. Oncol. 2017, 35, 3085. [CrossRef]

285. Gao, Y.; Nihira, N.T.; Bu, X.; Chu, C.; Zhang, J.; Kolodziejczyk, A.; Fan, Y.; Chan, N.T.; Ma, L.; Liu, J.; et al. Acetylation-dependent regulation of PD-L1 nuclear translocation dictates the efficacy of anti-PD-1 immunotherapy. Nat. Cell Biol. 2020, $22,1-12$. [CrossRef]

286. Jaccard, A.; Ho, P.-C. The hidden side of PD-L1. Nat. Cell Biol. 2020, 22, 1-2. [CrossRef]

287. Jiang, T.; Zhou, C.; Ren, S. Role of IL-2 in cancer immunotherapy. OncoImmunology 2016, 5, e1163462. [CrossRef]

288. Fukuhara, H.; Ino, Y.; Todo, T. Oncolytic virus therapy: A new era of cancer treatment at dawn. Cancer Sci. 2016, 107, 1373-1379. [CrossRef] [PubMed]

289. Shrivastava, S.; Raychoudhuri, A.; Steele, R.; Ray, R.; Ray, R.B. Knockdown of autophagy enhances the innate immune response in hepatitis C virus-infected hepatocytes. Hepatology 2010, 53, 406-414. [CrossRef] [PubMed]

290. Van Niekerk, G.; Hattingh, S.M.; Engelbrecht, A.-M. Enhanced Therapeutic Efficacy in Cancer Patients by Short-term Fasting: The Autophagy Connection. Front. Oncol. 2016, 6, 242. [CrossRef] [PubMed]

291. Dyer, A.; Frost, S.; Fisher, K.; Seymour, L. The role of cancer metabolism in defining the success of oncolytic viro-immunotherapy. Cytokine Growth Factor Rev. 2020, 56, 115-123. [CrossRef]

292. Hollingsworth, R.E.; Jansen, K. Turning the corner on therapeutic cancer vaccines. npj Vaccines 2019, 4, 1-10. [CrossRef]

293. Collins, N. Dietary Regulation of Memory T Cells. Int. J. Mol. Sci. 2020, 21, 4363. [CrossRef] [PubMed]

294. Castoldi, F.; Vacchelli, E.; Zitvogel, L.; Maiuri, M.C.; Pietrocola, F.; Kroemer, G. Systemic autophagy in the therapeutic response to anthracycline-based chemotherapy. OncoImmunology 2018, 8, e1498285. [CrossRef] [PubMed]

295. June, C.H.; Riddell, S.R.; Schumacher, T.N. Adoptive cellular therapy: A race to the finish line. Sci. Transl. Med. 2015, 7, 280ps7. [CrossRef] [PubMed]

296. Pietrocola, F; Kroemer, G. Caloric restriction promotes the stemness and antitumor activity of T lymphocytes. OncoImmunology 2019, 8, e1616153. [CrossRef]

297. Voss, M.; Wagner, M.; Von Mettenheim, N.; Harter, P.N.; Wenger, K.J.; Franz, K.; Bojunga, J.; Vetter, M.; Gerlach, R.; Glatzel, M.; et al. ERGO2: A Prospective, Randomized Trial of Calorie-Restricted Ketogenic Diet and Fasting in Addition to Reirradiation for Malignant Glioma. Int. J. Radiat. Oncol. 2020, 108, 987-995. [CrossRef]

298. Garg, A.D.; More, S.; Rufo, N.; Mece, O.; Sassano, M.L.; Agostinis, P.; Zitvogel, L.; Kroemer, G.; Galluzzi, L. Trial watch: Immunogenic cell death induction by anticancer chemotherapeutics. OncoImmunology 2017, 6, e1386829. [CrossRef] [PubMed]

299. Caloric Restriction in Treating Patients With Stage 0-I Breast Cancer Undergoing Surgery and Radiation Therapy (CAREFOR)Study Results. Available online: https:/ / clinicaltrials.gov/ct2/show/results/NCT01819233 (accessed on 25 October 2020). 